Idaho National Engineering Laboratory
The Impact of Microbially Influenced Corrosion on Spent Nuclear Fuel and Storage Life

J. H. Wolfram

R. E. Mizia

R. Jex

L. Nelson

K. M. Garcia

LOCKHEED MATTIN 


\section{DISCLAIMER}

This report was prepared as an account of work sponsored by an agency of the United States Government. Neither the United States Government nor any agency thereof, nor any of their employees, make any warranty, express or implied, or assumes any legal liability or responsibility for the accuracy, completeness, or usefulness of any information, apparatus, product, or process disclosed, or represents that its use would not infringe privately owned rights. Reference herein to any specific commercial product, process, or service by trade name, trademark, manufacturer, or otherwise does not necessarily constitute or imply its endorsement, recommendation, or favoring by the United States Government or any agency thereof. The views and opinions of authors expressed herein do not necessarily state or reflect those of the United States Government or any agency thereof. 


\section{DISCLAIMER}

Portions of this document may be illegible in electronic image products. Images are produced from the best available original document. 


\title{
The Impact of Microbially Influenced Corrosion on Spent Nuclear Fuel Storage Life
}

\author{
J. H. Wolfram \\ R. E. Mizia \\ R. Jex \\ L. Nelson \\ K. M. Garcia
}

Published October 1996

Idaho National Engineering Laboratory Lockheed Martin Idaho Technologies Company Idaho Falls, Idaho 83415 


\section{SUMMARY}

The task was undertaken to evaluate if microbial activity could be considered a threat to fuel integrity. The existing data regarding the impact of microbial influenced corrosion (MIC) on spent nuclear fuel (SNF) storage does not allow a clear assessment to be made. In order to identify what further data are needed, a literature survey on MIC was accomplished with emphasis on materials used in nuclear fuel fabrication, e.g., $\mathrm{Al}, 304 \mathrm{SS}$, and zirconium. In addition, a survey was done at Savannah River, Oak Ridge, Hanford, and the INEL on the condition of their wet storage facilities. These surveys included many useful sessions held with people involved with management and operations. The topics discussed were the SNF path forward, the types of fuel, ramifications of damaged fuel, involvement of microbial processes, dry storage scenarios, ability to identify microbial activity, definitions of water quality, and the use of biocides. Information was also obtained at international meetings in the area of biological mediated problems in spent fuel and high level wastes. Topics discussed included receiving foreign reactor research (FRR) fuels into existing pools, synergism between different microbes and other forms of corrosion, and cross contamination.

There are several different criteria for failed fuel. The EIS states that one through-wall pit that allows water to come into contact with fissile materials will cause the fuel to be considered failed. Operational personnel state that badly corroded fuel increases exposure to workers and requires longer handling time, causing schedule delays and cost impacts. Degraded fuel raises the issue of the structural integrity of the fuel and the potential for catastrophic failure. Although no nuclear criticality situations have occurred as a result of the corrosion processes, substantial alterations of fuel geometry due to corrosion could lead to critical reconfiguration while handling severely damaged fuel into dry storage. If the fuel is pitted in wet storage, there is uncertainty whether the drying process would be sufficient to halt the propagation of the pits. The SNF is required to be placed into dry storage "road ready" for eventual shipment to long term storage. Continued pitting while in dry storage would go undetected until the time of shipment, leading to the possibility of the SNF deteriorating to a point of failure. The risks associated with such an occurrence warrant further investigation into the impact of MIC on SNF.

The highlights of discussions held at Hanford, Oak Ridge, Savannah River Site (SRS), and at the INEL are:

- Basin water quality presently doesn't take into account the microbial population.

- Methods of measuring for microbial activity need to be distributed.

- Evidence of biofilms was present in all basins observed thus far. Biofilms have formed on test coupons in juxtaposition to the Advanced Test Reactor (ATR) and simulated SNF cans at the NNEL.

- $\quad$ SRB organisms, although not the only organisms shown to be involved in MIC, are good indications that MIC is or will be occurring. In order to have MIC, it is likely that a biofilm is present. The transfer of SNF from wet to dry storage won't eliminate the transfer of the biofilm and the microorganisms in it. The structure and materials of biofilm and the encapsulating material of microbes can greatly hinder the attempt to dehydrate. Various studies have shown the viability of biofilms and microbial activity in a humidified and unsaturated moisture environment. 
- $\quad$ Pitting has been observed, both at the INEL and SRS, that can't be explained abiotically. These data are from both the test cells and in the basins.

- Microbial issues were paramount in a FRR fuel shipment to SRS and can be expected to continue to be of importance. An acceptance criterion of FRR fuel needs to be addressed regarding microbial activity.

- Dry storage conditions may not prevent biofilm development and MIC.

The highlights of the literature survey were:

- Insufficient data exist from which a technical basis can be formed as the importance or nonimportance of MIC in relation to the severity of fuel deterioration, its integrity, or geometry alterations in wet storage, or in transitioning to dry storage, or in dry storage.

- MIC is not a new form of corrosion but acts as a precursor to a localized corrosion phenomenon such as pitting.

- The expected service life of industrial systems, including the safety systems of the nuclear . industry, have been substantially reduced due to MIC (Licina 1988).

- The localized corrosion resulting from MIC has caused through-wall penetrations in as little as 3 to 6 months in both $\mathrm{Al}$ (Schmitt 1986) and 304 SS (Licina 1988).

- There was no evidence found in the literature that zirconium or its alloys are susceptible to MIC.

- The MIC process is not caused by just a few microorganisms; many species have the ability to participate.

- MIC can occur in unsaturated conditions, in "clean" water, and in radiation fields.

- Biofilms play a crucial role in the MIC process. Their slow diffusion rates create micro environments at the metal surface, alter the microbe's physiology, retard the efficacy of biocides, and develop concentration cells.

- Microorganisms have the ability to concentrate metal ions, including radionuclides, to the order of $10^{6}$ accumulations (Little 1986).

Based on the preliminary work in FY-96, the following recommendations are put forward:

1. Assessment of the microbial component in CPP-666, ARMF/CRFMF, MTR, and CPP-603 fuel storage basins at the INEL. This assessment will produce a large set of data, of which the control data alone will gives rates and occurrences of localized corrosion. 
2. Develop and improve protocols for water quality in terms of microbial presence. This would include techniques for monitoring, mitigation, and prevention of biofilms on fuel assemblies. All surfaces have attached bacteria. This does not mean that these surfaces will suffer from biodegradation.

3. An evaluation of the role of MIC in fuel deterioration and the life cycle of fuel cans. Pitting propagation can continue in relatively dry atmospheres once it has been initiated.

4. An evaluation of the role of identified microbial activity and biofilms on the SNF drying process. Recent drying tests did not remove moisture from dirt and clay deposition on the fuel.

5. Assessment of dry storage issue based on an evaluation of the role of microbial activity continuing in fuel channels during dry storage.

6. The dry storage behavior of the Omega West Reactor fuel stored at Los Alamos should be assessed and documented in the first quarter of FY-97 before this fuel is sent to SRS for wet storage.

7. Assessment of the impact of FRR fuels contaminating SRS and INEL pools with variant microbial activity or nutrients for microbes.

In conjunction with these tasks, an effort will be made to share this information with other DOE sites for their use. Personnel who have been trained in monitoring for microbial activity would be available to work with the other DOE sites so that measurements taken across the complex can be compared. 



\section{CONTENTS}

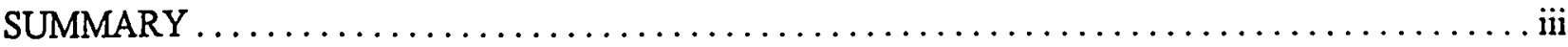

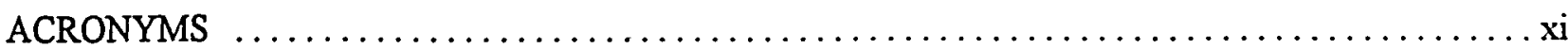

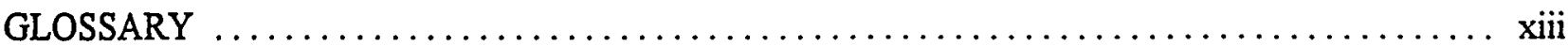

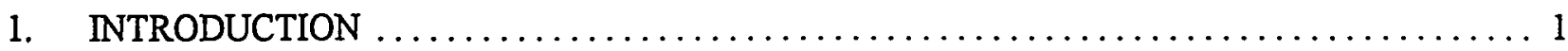

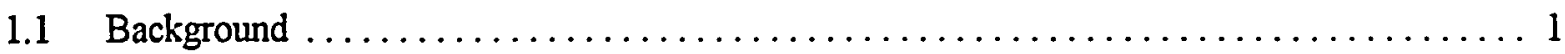

1.1.1 Spent Nuclear Fuel Storage Experience $\ldots \ldots \ldots \ldots \ldots \ldots \ldots \ldots \ldots \ldots \ldots$

1.1.2 Microbially Influenced Corrosion's Role in Wet Storage $\ldots \ldots \ldots \ldots \ldots \ldots \ldots$.

1.1.3 Microbially Influenced Corros̀ion's Role in Dry Storage $\ldots \ldots \ldots \ldots \ldots \ldots \ldots 2$

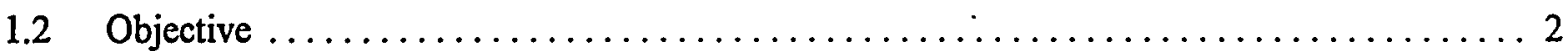

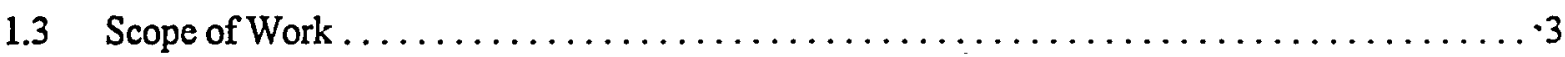

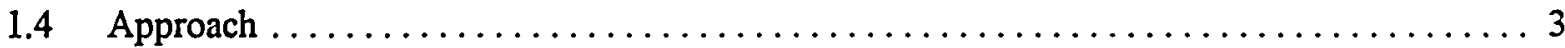

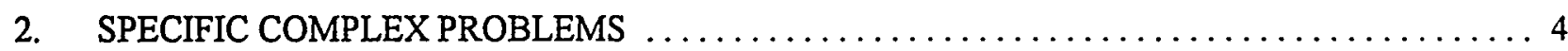

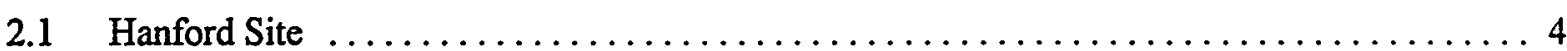

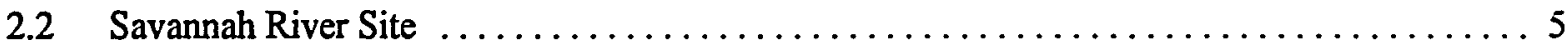

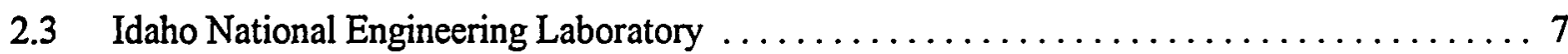

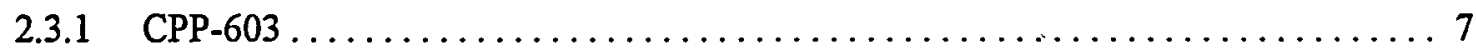

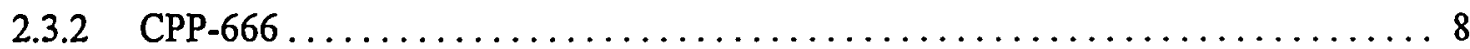

3. ASSESSMENT OF MICROBIAL INFLUENCED CORROSION $\ldots \ldots \ldots \ldots \ldots \ldots \ldots \ldots$

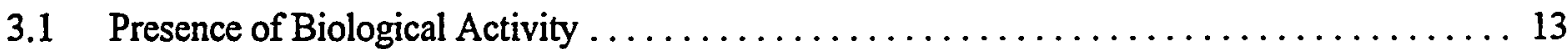

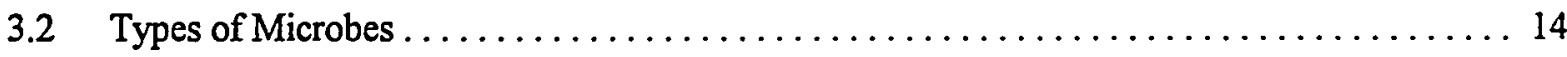

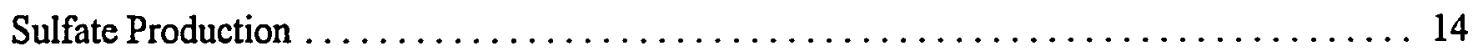

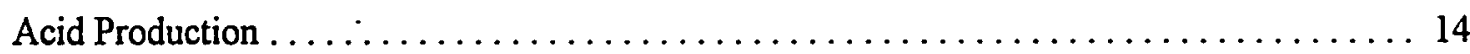

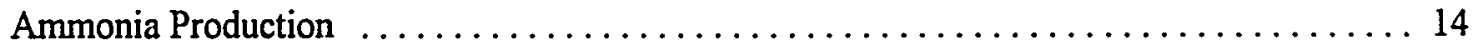

Metal Deposition .............................................. 14

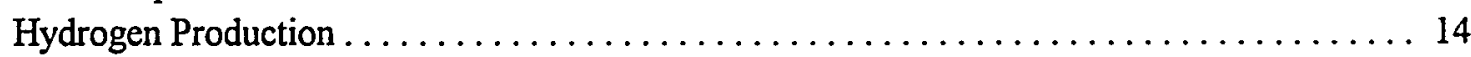




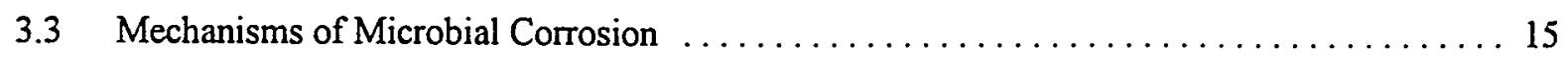

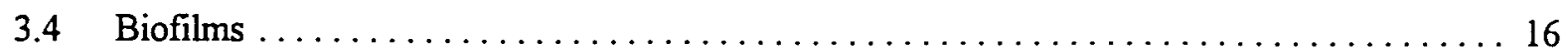

3.5 Impact of Drying on Biofilms and MIC $\ldots \ldots \ldots \ldots \ldots \ldots \ldots \ldots \ldots \ldots \ldots \ldots \ldots \ldots \ldots \ldots \ldots$

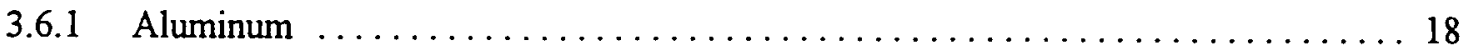

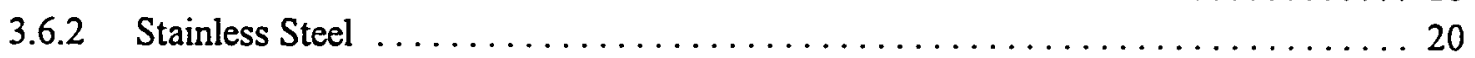

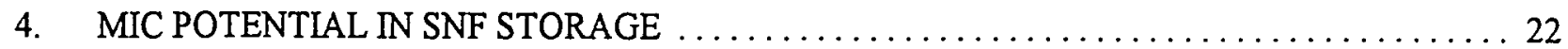

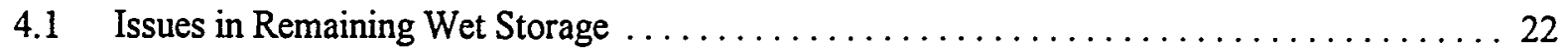

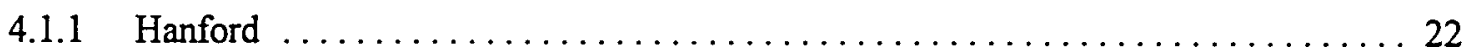

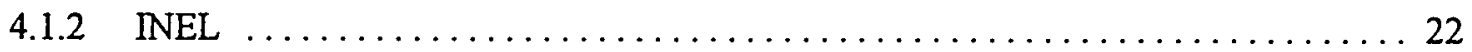

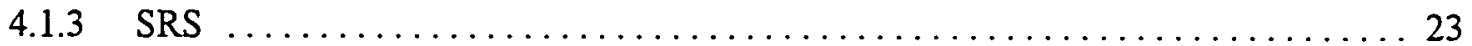

4.1.4 General Observations-Aluminum and Stainless Steel ............... 23

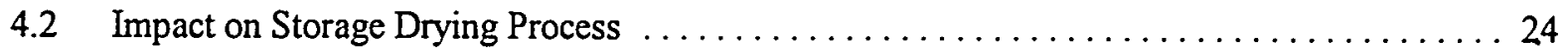

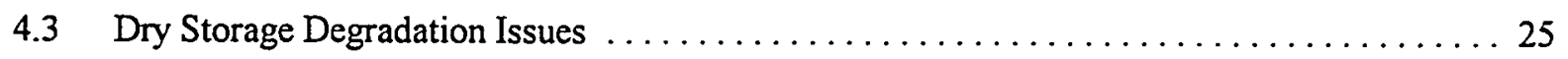

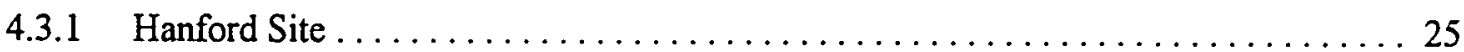

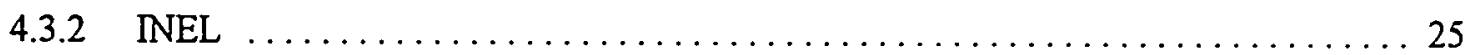

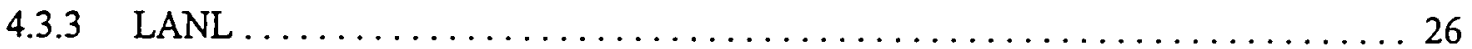

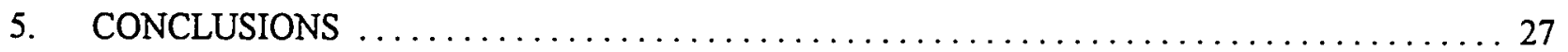

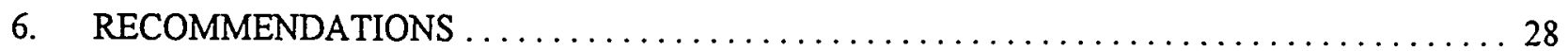

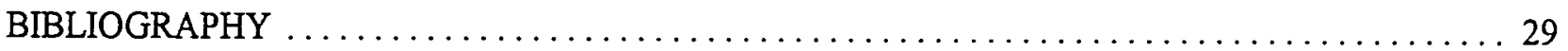

Appendix A-MIC Techniques and Methodology

Appendix B-Tasks to be Done at the INEL

Appendix C-Trip Reports

Appendix D-Biocide Addition Corrosion Test Plans

Appendix E-Photographs 


\section{FIGURES}

1. As shown in Figures 1 and 2, the acid producers have turned the selective $\mathrm{pH}$ media

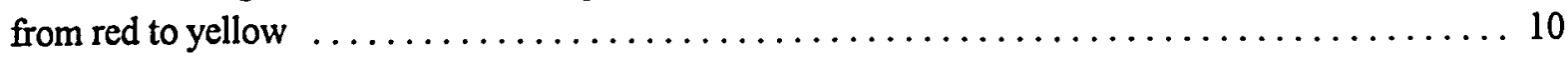

2. Acid producers were found on both $304 \mathrm{SS}$ and $6061 \mathrm{Al}$ coupons $\ldots \ldots \ldots \ldots \ldots \ldots \ldots$

3. As shown in Figure 3, acid-producing bacteria are evident in the red-capped bottles that have changed from red (right bottle is the sterile control) to yellow $\ldots \ldots \ldots \ldots \ldots \ldots \ldots$

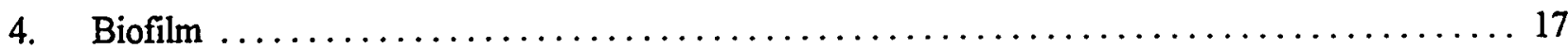

5. The stages of biofilm development $\ldots \ldots \ldots \ldots \ldots \ldots \ldots \ldots \ldots \ldots \ldots \ldots \ldots \ldots \ldots \ldots$

6. Scanning electron micrograph of $\mathrm{Al}$ sample exposed to tap water for four months.

The faceted corrosive attack is consistent with MIC $\ldots \ldots \ldots \ldots \ldots \ldots \ldots \ldots \ldots \ldots$

\section{TABLES}

1. Types of bacteria that directly cause corrosion in metals. $\ldots \ldots \ldots \ldots \ldots \ldots \ldots \ldots \ldots \ldots$

2. Average results from various drying procedures. $\ldots \ldots \ldots \ldots \ldots \ldots \ldots \ldots \ldots \ldots \ldots$ 


\section{ACRONYMS}

\begin{tabular}{|c|c|}
\hline $\mathrm{Al}$ & aluminum \\
\hline ATR & Advanced Testing Reactor \\
\hline $\mathrm{CS}$ & carbon steel \\
\hline DOE & U.S. Department of Energy \\
\hline FRR & Foreign Research Reactor \\
\hline INEL & Idaho National Engineering Laboratory \\
\hline kGy & kilo Gray \\
\hline LANL & Los Alamos National Laboratory \\
\hline MIC & microbial influenced corrosion \\
\hline mpy & mils per year \\
\hline MTHM & metric tons (heavy metal) \\
\hline ORNL & Oak Ridge National Laboratory \\
\hline RBOF & Receiving Basin for Offsite Fuels \\
\hline RH & relative humidity \\
\hline SNF & spent nuclear fuel \\
\hline SRB & sulfate-reducing bacteria \\
\hline SRS & Savannah River Site \\
\hline SS & stainless steel \\
\hline TMI & Three Mile Island \\
\hline$\mu \mathrm{S} / \mathrm{cm}$ & micro-siemens per centimeter \\
\hline
\end{tabular}


-

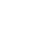

. 


\section{GLOSSARY}

Aerobe: An organism that requires oxygen to live.

Aerobic: Exposed to oxygen.

Algae: A heterogeneous group of photosynthetic plants ranging from microscopic single-cell forms to multicellular, very large forms such as seaweed.

Anaerobe: An organism that lives without oxygen.

Anode: The electrode of an electrolyte cell at which oxidation occurs. Electrons flow away from the anode in the external circuit. Corrosion occurs at this electrode, and metal ions enter the solution.

Bacteria (Bacterium): Any of a large group of microscopic organisms that are often aggregated into colonies, are enclosed by a cell wall or membrane (procaryotes), and lack fully differentiated nuclei. Bacteria may exist as free-living organisms in soil, water, or organic matter, or as parasites in the live bodies of plants and animals.

Biocide: A compound toxic to any living thing.

Cathode: The electrode of an electrolytic cell at which reduction takes place. Electrons flow toward the cathode in the external circuit. Typical cathodic processes are cations taking up electrons and being discharged, oxygen being reduced, and the reduction of a metallic element or group of elements from a higher to a lower valence state.

Concentration Cell: A corrosion cell in which the driving force is caused by a difference in concentration of a component in the electrolyte.

Corrosion Potential $\left(\mathbf{E}_{\text {corr }}\right)$ : The potential of a corroding surface in an electrolyte relative to a reference electrode. Also called rest potential, open circuit potential, freely corroding potential.

Crevice Corrosion: A form of localized corrosion occurring at locations where easy access to the bulk environment is prevented, such as at the mating surfaces of metals or assemblies or metals and nonmetals (see Concentration Cell).

Electrochemical Cell: An electrochemical system consisting of an anode and a cathode in electrical contact and immersed in an electrolyte. The anode and cathode may be different metals of dissimilar areas on the same metal surface.

Exopolymer: An Extracellular material, frequently sticky, that defines the shape of organisms and serves to trap particulate matter.

Facultative Cells: Bacterial cells that can live either in the presence or absence of oxygen. 
Fungus (Fungi): Any of a major group of parasitic plants that lack chlorophyll, including molds, mildews; smuts, mushrooms, and yeasts.

Metabolism: The entire set of enzyme-catalyzed transformations of organic nutrient molecules in living cells.

Metabolite: A chemical intermediate in the enzyme-catalyzed reactions of metabolism.

Microbe: A microscopic organism; applied particularly to bacteria.

Microorganism: Any organism of microscopic size that requires a microscope to be seen.

Passivation: A reduction of the corrosion rate of a metal due to formation of a protective film, usually an oxide, on its surface.

Pits, Pitting: Localized corrosion of a metal surface that is confined to a small area and takes the form of cavities.

Plankton (Planktonic): Microorganisms floating or drifting in a body of water.

Sessile: Attached to a surface.

Slime: An extracellular material produced by some microorganisms, characterized by a slimy consistency of varied chemical composition.

Sterile: Free of any living organisms.

Sulfate-Reducing Bacterium (SRB): Any organism that metabolically reduces sulfate to $\mathrm{H}_{2} \mathrm{~S}$; includes a variety of microorganisms (see Desulfovibrio).

Thermophile (Thermophilic): An organism that grows best at temperatures greater than $50^{\circ} \mathrm{C}\left(122^{\circ} \mathrm{F}\right)$.

Tuberculation: The formation of localized corrosion products scattered over the surface in the form of knoblike mounds called tubercles. 


\section{The Impact of Microbially Influenced Corrosion on Spent Nuclear Fuel Storage Life}

\section{INTRODUCTION}

\subsection{Background}

\subsubsection{Spent Nuclear Fuel Storage Experience}

Spent nuclear fuel from the nuclear navy, from research reactors, and from nuclear weapons production has been accumulated within the DOE complex. Most of the fuel is currently in wet storage at the Idaho National Engineering Laboratory (INEL), the Savannah River Site (SRS), Hanford Site, West Valley Demonstration Site, and Oak Ridge National Laboratory (ORNL). Due to the decision to discontinue nuclear fuel reprocessing, spent fuel has accumulated in water basins originally designed to provide short-term storage. Corrosion of spent fuel stored in water basins has become an issue of concern due to leaching of fissile materials and fuel integrity. This concern will remain as long as the fuel is in interim storage or knowledge is gained that will mitigate the aging events in relation to fuel integrity.

The schedule for transfer of SNF from wet to interim dry storage shows that this activity will be competed by 2006 . Interim dry storage could allow for SNF to be exposed to atmospheric conditions. The presence of humidity is sufficient for localized corrosion to continue. At this time, the transfer from the interim vented 304 SS canisters to sealed dual-purpose canisters is not scheduled. It is anticipated that dry storage will provide a stable and less-expensive method of SNF storage. Ultimately, each DOE site will provide wet and dry storage facilities for a particular spent nuclear fuel. For example, the INEL and SRS will be the central storage facility for SS- and Al-clad spent fuels, respectively. Transferring fuel from wet storage to an interim dry storage facility is anticipated to reduce the cost of storage and abate any further aging processes from occurring. In most cases, the abatement of the aging process has not been thoroughly evaluated, especially for fuel that is already corroded and damaged.

Corrosion of fuel assemblies and other basin components have been observed at the Hanford site, the INEL, and SRS facilities, which all have wet storage. Corrosion excursions have resulted in releases due to cladding breaches. Although no nuclear criticality situations have occurred as a result of the corrosion processes, substantial alterations of fuel geometry due to corrosion could lead to critical reconfiguration while handling severely damaged fuel into dry storage. This concern is coupled with the lack of current knowledge on whether further deterioration will be abated by dry storage. Data are needed on the extent of the deterioration in order to predict storage life and maintain safety levels.

\subsubsection{Microbially Influenced Corrosion's Role in Wet Storage}

Several factors have led to extensive deterioration of the fuel, such as physical damage due to handling, but the primary corrosion mechanism is pitting. Pitting is a form of localized corrosion of a metal surface that results in cavities. Pitting is most common in metals that form an adherent passive surface film such as $\mathrm{Al}$ and $304 \mathrm{SS}$. The pits tend to develop at defects or flaws in the surface film and at sites of mechanical 
damage. The rates of pitting can be quite rapid (e.g., 5,000 mils/yr) under specific conditions and can be one of the most destructive forms of corrosion. In the case of stored Al-clad-or SS-clad SNF in basin water, pitting can penetrate the clad material and allow the release of uranium, plutonium, cesium-137, and other radionuclides due to reaction with fuel meat. As an example, tests performed at the SRS P, K, L basins showed that pitting can completely penetrate coupons $750 \mu \mathrm{m}$ (30 mil) thick in 45 to 100 days in water with the following characteristics: conductivity $>180 \mu \mathrm{S} / \mathrm{cm}, \mathrm{pH} 6.3$ to 7.1 , and chloride up to $18 \mathrm{ppm}$ (Howell 1993; Howell 1995a). MIC is a form of localized corrosion. Pit initiation can be a result of microbial activity on the surface of the metal. Once the pit in initiated, propagation can continue despite environmental changes.

As SNF is moved out of wet storage into dry storage, degraded fuel will increase the potential of exposure levels to workers and safety problems. Most reports on fuel being dropped during transfer attribute the failure to the attachment points on the fuel.

It can't be predicted at present whether pitting activity will be substantially reduced or mitigated during the SNF drying process and subsequent dry storage. Pits can cease to grow due to several causes: an increase of the local cell internal resistance, polarization of the cathode and/or the anode, loss of moisture (pits become dry), or buildup of corrosion product in the pit cavity, reducing the flow of metal cations. Active pitting may not cease during the drying process or may be reinitiated if a dried pitted surface is returned to its original . environment or sufficient humidity.

\subsubsection{Microbially Influenced Corrosion's Role in Dry Storage}

The operational assumption is that transferring SNF from wet storage to dry storage should terminate pitting activity. The only reason pitting could continue is if the presence of moisture would allow for either an electrochemical reaction to continue or a biofilm could form or remain on the surface of the metal, allowing for MIC. The initiation and propagation of pitting can be enhanced by the presence of a biofilm. A schematic diagram of pitting in the presence of a biofilm is shown in Figure 1 (see Section 3). The metal surface under a biofilm may be in completely anaerobic conditions as the top layers of the biofilm deplete the oxygen concentration. The rate of pitting can be enhanced under anaerobic conditions. Thus, the biofilm can indirectly cause an increase in the pitting rate.

The following questions need to be answered:

What is not known is the ability of the biofilm and microbes to survive in dry storage. If their survival can be predicted, then is there a need to know just how much damage can be expected by their presence on SNF and at what rate?

\subsection{Objective}

The objective of this task was to evaluate if MIC could be so extensive and destructive that substantial degradation of SNF should be expected in the next 20 to 40 years. Many assumptions are being used to make decisions regarding fuel storage at this time. A true basis is needed for decisionmaking, and it must be founded on real data. Any threat to the stability of SNF must be thoroughly characterized. 


\subsection{Scope of Work}

Funding in FY-96 was provided to perform a literature search on MIC in SNF storage and relevant case studies and learn the status of efforts at several DOE complex facilities that store SNF. This task has generated constructive discussion among many technical and operational personnel and has helped clarify where the potential risk drivers are within the ongoing plans to transfer SNF to dry storage.

These efforts are summarized in this report. The purpose of this report is to explain why it is not yet possible to evaluate risk associated with MIC and to point out the data that are needed for decisionmaking on dry storage operations.

\subsection{Approach}

What was known at the start of the task was that there has been substantial degradation at the INEL in the CPP 603 fuel storage basin due to poor water quality and microbes in the water. There is pitting corrosion on Al in CPP-666 that is not totally explained by normal corrosion mechanisms. Drying tests at the INEL have shown that there will be difficulty in completely drying Al plate fuels, which will result in a damp corrosion product sludge remaining in the SNF cooling channels (Lords 1996). Although this drying data exist and other studies discuss the rate of MIC in wet storage, no data exist on microbial activities relating to rates of localized corrosion or pit density on SNF in dry storage.

The approach taken at the INEL and other DOE sites was to hold detailed discussions on SNF degradation with operations and technical personnel and the impact of that degradation on cost and schedule for SNF wet and dry fuel storage. Other tasks have been to review corrosion information from other DOE sites and the literature in an attempt to provide a coherent status of MIC in SNF pools and to analyze if past investigations have properly collected data that would rule out or point to MIC. A current status was needed of how operations of SNF storage are affected by microbial activity.

Evaluation of MIC on SNF cannot be done at this time because acceptance of MIC is relatively recent by the scientific/engineering community. In practice, MIC is identified as a causative corrosion mechanism only after no alternative mechanisms can reasonably explain the observed corrosion and after several methods have indicated the possibility of MIC. This is difficult, however, because most existing methods rely on direct visual observation, which can't detect microbes and destructive metallographic preparation techniques that will destroy all evidence of microbes. MIC investigation methods are being developed rapidly. Currently, investigators are attempting to develop several methods to assess the occurrence of MIC. Very few, if any, of these techniques have been used for remote investigations of MIC in radiation fields. Only indirect surveys in fuel pools have been accomplished using test coupons, etc., for the presence of MIC. 


\section{SPECIFIC COMPLEX PROBLEMS}

Storage of spent fuel in government-owned water basins was begun in the early $1950 \mathrm{~s}$. The basin water level is typically $30 \mathrm{ft}$ deep with fuel storage equipment located at the bottom. The water provides shielding and thermal cooling for the fuel rods. Water is introduced at one end of the pool and is removed from the other end. Water at the bottom of the pool recirculates when the fuel rods are thermally hot, but does not recirculate as rapidly when the fuel cools. This lack of recirculation causes near-stagnant-water conditions in the vicinity of the fuel.

Initially, these pools provided temporary storage and cooling before reprocessing. The water treatment systems for these pools were crude, and corrosion was not considered to be an issue due to the short storage times and ultimate reprocessing. However, many of the fuels have been in water storage much longer than was originally planned (up to 30 years). During this 40 -year experience with fuel storage, corrosion has become a concern due to the leaching of radioactive materials from the spent fuel. A brief summary of the storage experience for each site is presented in the following section.

\subsection{Hanford Site}

Spent fuels irradiated in the Hanford N-Reactor and the single pass reactor are currently stored in the * $\mathrm{K}$-East and $\mathrm{K}$-West basins at Hanford. The single-pass Al-clad fuel elements are stored in the K-East Basin. More than 2,000 metric tons of enriched uranium metal clad in Zircaloy-2 ( $N$-reactor fuel) is stored in the two basins. This represents about $80 \%$ of the spent nuclear fuels inventory in the DOE complex, on a heavy metal weight basis. K-East and $\mathrm{K}$-West basins were designed to provide temporary storage for spent fuel prior to chemical processing. The basins operated in a feed-and-bleed, once-through mode using raw river water from 1954 to 1971 . Beginning in 1973, the K-East basin was upgraded and changed to a closed-cycle water basin in preparation for the storage of $\mathrm{N}$-reactor fuel. The concrete basin surfaces were not cleaned or coated, and the basin was filled with filtered river water, which resulted in the introduction and growth of bacteria in the upgraded basins. Various algaecides and chlorine were used to control algae and bacteria growth. A high percentage of the $\mathrm{N}$-Reactor fuel was breached during unloading and handling. The fuel was stored in open top $\mathrm{Al}$ cans with the uranium metal exposed directly to the basin water. The leach rate for radioactivity from the damaged fuel into the basin water was about $1.2 \mathrm{Ci} /$ day at $50^{\circ} \mathrm{C}$ and $3.5 \mathrm{Ci} /$ day at $70^{\circ} \mathrm{C}$.

Three ion exchange columns and a sand filter were added to the K-East water treatment system in 1978. The ion exchange columns were operated periodically then continuously to reduce the basin water radionuclide concentration. Before installation of a basin water cooling system in 1983, the radionuclide release rate was three times higher in the summer than in the winter due to higher water temperatures. Currently, the K-East basin has a considerable amount of sludge on the floor (at some locations, as much as 31 inches exist).

Severe pitting corrosion of $\mathrm{Al}$ alloy fuel storage canisters in $\mathrm{K}$-East basin occurred during the storage period. Pitting was believed to be caused by the use of a chlorine based algaecide which attacked the coppernickel heat exchanger tubes, dissolving the copper into the basin water. Copper is a known promoter of pitting corrosion of Al. A similar high corrosion rate occurred on the copper-nickel surveillance specimens in the basins during the same time period. Corrosion rates on the order of 0.01 to $0.02 \mathrm{mpy}$ have been observed 
over the past 10 years at the low conductivity levels achieved by the mixed bed deionizers. The possible . effect of MIC was never evaluated. Most of the severe corrosion damage appears to have been done during the early 1980 time frame. (NOTE: Visual inspection suggests that Al canister corrosion is minimal in KWest Basin). Single-pass Al-clad fuel elements stored in K-East are reported to have minimal degradation. Their surface film would be different due to the exposure to reactor conditions. These fuel elements are now obscured by sludge.

A corrosion monitoring program was implemented by Westinghouse Hanford in 1980 to determine the uniform corrosion rates of the major materials in the basin environment. Corrosion coupons, including 1018 carbon steel, 2410 copper-nickel alloy, $5086 \mathrm{Al}$, and $6061 \mathrm{Al}$ alloys were installed in 1980. After storage times from several weeks to several years, the samples were removed from the basins and analyses made to determine corrosion rates. The corrosion rates showed accelerated corrosion in the early 1980 s due to the biocide chemical addition. For the $\mathrm{Al}$ alloys, severe pitting corrosion was noted, resulting in high corrosion rates in K-West and K-East in the early 1980s. Water chemistry control measures reduced the general corrosion rates to low levels. MIC was never evaluated as part of the corrosion program (Johnson 1995).

\subsection{Savannah River Site}

SRS has produced weapons material in production reactors. Storage of Al-clad fuel and target assemblies in the reactor disassembly basins at the SRS has been successful over $40+$ years of plant operations. Pitting corrosion of SNF stored in the water-filled basins while awaiting processing has, however, been a periodic concern during several time periods over the history of plant operations. These excursions have been attributed to water chemistry problems (Howell 1996). This paper described various corrosion studies of the piitting problems in the $L, K$, and $P$ Basins and the resultant water cleanup effort. The makeup water for these basins was originally filtered, untreated well water of high conductivity (personal communication with J. P. Howell, 1996). The water as of October 1996 is deionized with a conductivity of less than $3 \mu \mathrm{S} / \mathrm{cm}$.

The Receiving Basin for Offsite Fuels (RBOF) facility at SRS is the primary storage basin for domestic and FRR fuel from the U.S. and other parts of the world. This facility has always had deionized water of low conductivity ( 1 to $3 \mu \mathrm{S} / \mathrm{cm}$ ). There has been no visible evidence of corrosion on the $\mathrm{Al}$ canisters that house most of the fuel or on $6061 \mathrm{Al}$ alloy storage racks. However, concerns were raised about the possibility of MIC degradation of the SNF due to FRR fuel receipts.

Experimentation and sampling were performed in the RBOF basin at SRS addressing several MIC concerns. Results from the sampling are discussed in a letter by J.P. Howell, SRT-MTS-95-0114. In October 1994, sampling of the microbiological activity of the RBOF bulk basin water was initiated before and after the first shipment of foreign research reactor (FRR) fuel was stored in the basin. Even though these measurements were only 1 week apart, the overall bacteria density of the basin water increased greatly. The total concentration of sulfate-reducing bacteria (SRB) in the basin water was initially found to be less than $100 \mathrm{cells} / \mathrm{mL}$, but measured two orders of magnitude higher 1 week later. SRB are known types of organisms associated with MIC as well as an indicator that biofilms exist in aerated water.

SRB have played a key role in corrosion of iron and 304 SS systems in other industrial applications and have been shown, especially in aircraft $\mathrm{Al}$ fuel tank systems, to cause $\mathrm{MIC}$ in $\mathrm{Al}$ alloys. SRB are anaerobic 
bacteria that can maintain life, but do not generally show growth in fully oxidizing (aerobic) conditions, such as exists in the RBOF basin. The increase in the bacteria concentrations in the basin was attributed to bacteria deposited from the FRR fuel into RBOF or the FRR fuels providing nutrients to stimulate existing bacteria growth in the basins.

Although it is difficult to assess whether the dramatic increase in SRB can be attributed to the internment of the FRR, the real concern is that an increase was observed. Since SRB are organisms that often attach to surfaces and locate under or within biofilms, the dramatic increase seen in the planktonic population infers that the increase came from a new source or due to substantial disturbances of the surfaces in the RBOF basin. Followup studies should be performed to further delineate the sources of the SRB, the activity of the SRB, the extent of SRB on RBOF basin surfaces including fuel assemblies, and FRR surfaces. In addition, a population profile of other microbial types should also be performed on both planktonic and sessile content. These types of studies fall within a microbial assessment of the complex facilities, which will provide a foundation on background microbial ecological information.

The two fuel storage basins where the possibility of MIC has been evaluated are the INEL and SRS. Some areas of concern that are in need of further clarification are described in Issues Related to the Potential for Microbiological Influenced Corrosion in the RBOF Fuel Storage Basin (Howell 1995b). Of particular interest are the causes for bacterial population growth.

Some of the issues described by Howell and the authors' responses are as follows:

"The increase in bacteria population of RBOF in October 1994 was initially attributed to the storage of FRR Fuel. Both INEL and Montana State University (MSU) believe that this increase was more likely based on a change in nutrients in the basin from other sources. Data from the CPP-666 basin routinely shows cyclic changes (1-2 orders of magnitude) in basin population due to temperature and chemistry changes in the basin." The basis for this conclusion was on past experience and knowledge but not on actual microbial measurements. Past measurements of bacterial population growth have not been able to pinpoint the cause of the growth.

"INEL/MSU do not believe that there is a correlation between bacteria population numbers in the basin or on the metal and corrosion of a metal system in that environment. It is the specifics of the bacteria, the biofilm, and how the bacteria attaches itself to the sample that determine the corrosion at a later time." Again, there have been no data to form a strong basis for concluding that there is or isn't a correlation between the microbial populations and metallic corrosion.

The Savannah river Technical Center (SRTC) experiment is designed to evaluate the potential for MIC in RBOF and to evaluate the effectiveness of biocides in mitigating microbiological activity. The SRTC experiment program was initiated during 1996, but experimental difficulties caused early termination of the first set of tests. New tests are currently under way using improved water sterilization techniques.

SRB organisms, although not the only organisms shown to be involved in MIC, are good indications that MIC is or will be occurring. In order to have MIC, it is likely that a biofilm is present. The transfer of SNF from wet to dry storage won't eliminate the transfer of the biofilm and the microorganisms in it. The 
structure and materials of biofilm and the encapsulating material of microbes can greatly hinder the attempt to dehydrate. Various studies have shown the viability of biofilms and microbial activity in a humidified and unsaturated moisture environment.

\subsection{Idaho National Engineering Laboratory}

DOE-owned Al, 304 SS, and zirconium-clad SNF have been stored at the Idaho Chemical Processing Plant in the CPP-603 Basin since 1951. A new storage facility, CPP-666, was constructed and put into operation in 1984. These two facilities have experienced corrosion problems over the course of their operating history.

\subsubsection{CPP-603}

CPP-603 is the oldest of the two facilities, having stored SNF since 1951. It consists of three unlined concrete pools (north, middle, and south) filled with water and holds 41 different types of SNF received as early as 1959. The CPP-603 pools are interconnected to form an E-shaped basin. The SNF has been removed from the north and middle basins in 1996. This fuel was moved to the south basin of CPP-603 and CPP-666. The north and middle pools stored fuel in buckets or cans suspended from a monorail system. The south pool stores fuel in Al and SS racks. The fuel types stored in this pool include metals, alloys, hydrides, and oxides in several different fuel matrices. The majority of the SNF is clad with Al, SS, and Zircaloy, but some SNF is unclad or known to have defective cladding.

Evaluation of the fuel and storage equipment conditions were made in CPP-603. Periodic visual inspections, including underwater video inspections, are made of the concrete structure, the monorail, hangers, buckets and cans, and some of the fuel. Four different materials have been evaluated in these inspections: 304 SS, zirconium alloys, CS, and $6061 \mathrm{Al}$. No appreciable corrosion has been detected on the zirconium and 304 SS. CS has corroded extensively and is being replaced with 304 SS for the handling equipment. $6061 \mathrm{Al}$ has shown preferential attack in the form of pitting and crevice corrosion. The amount of attack is dependent on exposure time in the basin water. The Al mesh material that was used as a barrier has also shown extensive attack and has failed on Al racks and test coupons (Dirk 1994; Hoskins et al. 1993; Lundberg 1994).

Based on the design and sequence of events in the storage environment, the key considerations in evaluating this environment include the following points:

- Long service time (40 years)

- Unlined concrete surfaces and possibly radionuclide diffusion through the pool wall

- Development of an aggressive pool chemistry due to addition of algaecides (up to $800 \mathrm{ppm}$ chloride): algaecides included calcium hypochlorite, chlorine, and iodine

- Nitrate inhibitors introduced to mitigate corrosion $\left(\mathrm{NO}_{3} / \mathrm{Cl}^{-}\right.$between $3: 1$ and 5:1)

- Once-through water flow until 1966 
- Use of reverse osmosis and occasional water replacement to lower the impurity levels

- Ultraviolet lights installed to treat inlet water, mitigating algae growth

- Chloride levels at about $50 \mathrm{ppm}$ in 1994.

\subsubsection{CPP-666}

CPP-666 is a modern underwater fuel storage facility that was placed in operation in 1984 and has six 304L SS-lined storage pools with 304 SS and 6061Al storage racks and equipment for monitoring and treating the water. Sixteen types of SNF are stored in CPP-666 with various combinations of SS, Al, and Zircaloy cladding and fuel matrices. This facility will continue interim wet storage of SNF until other options exist; plans are under way to move portions of the SNF from both CPP-603 and CPP-666 to dry storage within the next 6 years (Hoskins et al. 1993). Other schedules show that CPP-666 will not be defueled in 2006.

The pool chemistry in CPP-666 is more benign than that of the CPP-603, but is not free of corrosion. The base metal and welds of the 304L SS basin liner have not exhibited pitting and have a general corrosion rate of $2.5 \mu \mathrm{m} / \mathrm{yr}(0.01 \mathrm{mpy})$.

An inspection program similar to that used at CPP-603 is in place at CPP-666. The program includes periodic examinations of the 304L SS liner, 6061 and $1100 \mathrm{Al}$, and 304 SS "tie-plate" coupons representing the storage racks and simulated SNF $6061 \mathrm{Al}$ cans. Some pitting has occurred on $6061 \mathrm{Al}$ coupons; the 1100 Al coupons have not yet been examined. Two types of simulated SNF 6061 Al storage cans were inspected. In the most recent inspection of the simulated SNF storage cans, pit initiation was detected. Pitting was seen randomly located on the outside surface of the can. Water was found on the inside of one can, indicating through-wall pitting of the can. This localized corrosion appears without the presence of corrosion product. The pattern seen on the outside of the can is characterized by a shiny "halo" with a pit within the "halo". This pattern of localized corrosion needs further investigation. Since a biofilm was found on the coupons, the possibility of MIC is being investigated (Dirk-32-92; Dirk-29-93).

304 SS and $6061 \mathrm{Al}$ corrosion coupons have been immersed in the basin and evaluated semi-annually over the past 10 to 13 years. The welded 304 SS plate has shown no attack after 13 years of exposure. Expanded metal mesh and woven metal mesh Al coupons have been used to duplicate screens used on $\mathrm{Al}$ racks in the basin. The coupons have been inspected every 6 months and in 1994 had about 10.6 years of exposure. The Al has shown a general attack of 1.5 mpy with preferential attack in the form of pitting and crevice corrosion.

Along with the various experimentation and studies on the CPP-666 facility, high bacterial levels were noted where the zircaloy, $304 \mathrm{SS}$, and $6061 \mathrm{Al}$ fuel is stored. The CPP-666 basin water inlet filter is a source of high bacteria levels. The filter, which is located before the resin deionization system, is not routinely cleaned unless severe microfouling takes place. Severe biological fouling has occurred on these 304 SS plates. In addition, the resins used for deionization have never been regenerated over the 10 years of operations, and there has been a breakthrough on radionuclides. Bacteria measurements of the water after going through the deionizer show an order of magnitude in increase in population, indicating that the bacteria 
are plentiful in the resin bed. In contrast, the filters at RBOF are recharged every week and are washed in oxalic acid about once a year, making it difficult for bacteria to live and accumulate. In addition, the resins at RBOF are regenerated about every 6 months using nitric acid. CPP- 666 has no sand filter purification system like the RBOF basin. Discussions on the differences between CPP-666 operations and RBOF operations led to the conclusions that the conditions in the CPP- 666 basins were more conducive to microbial activity.

"The water quality of the INEL CPP-666 spent fuel storage basin is the best in the country. With its low chloride concentration and conductivity, corrosion of stored fuels has not been a problem since it was constructed. In 1992-1993, however, pitting was observed in aluminum corrosion coupons immersed in the CPP- 666 basin water. The pitting was characterized by extremely small penetrations, invisible from a few feet away, and no visible aluminum oxide corrosion product was observed. Pits ranged in depth from a few mils to 100 mils. Typical fuel cladding thickness ranges from 15 to 30 mils. A slime-like film was seen on some components stored in the basin and covering some of the pits on aluminum corrosion coupons (Howell 1995a)."

Initial Evaluation of Dry Storage Issues for SNF in Wet Storage at ICPP (Guenther et al. 1996) compares CPP-666 and RBOF. "Based on Al-alloy corrosion behavior in other pools with well-conditioned waters (e.g., RBOF), Al-alloy fuels and components should be expected to have excellent durability in the CPP-666 pool. See Kustas et al. (1991) for quantitative data for RBOF water chemistry. Caskey (1993) and Howell et al. (1993) cite favorable extended performance of Al alloys in RBOF. However, reports at the INEL (Dirk 32-92) of pitting attack mean that the INEL is not in a position to ensure the long-term performance or durability of Al-alloys fuels and components in CPP-666. Degraded Al alloy fuels transferred from other locations could continue corroding and could also contribute to the corrosion of the presently stored fuel in CPP-666.

Similar organisms exist in both CPP-603 and CPP-666. These organisms found were classified as $\mathrm{SRB}$, acid-producing bacteria, and other heterotrophic bacteria (see Figures 1, 2, and 3). 


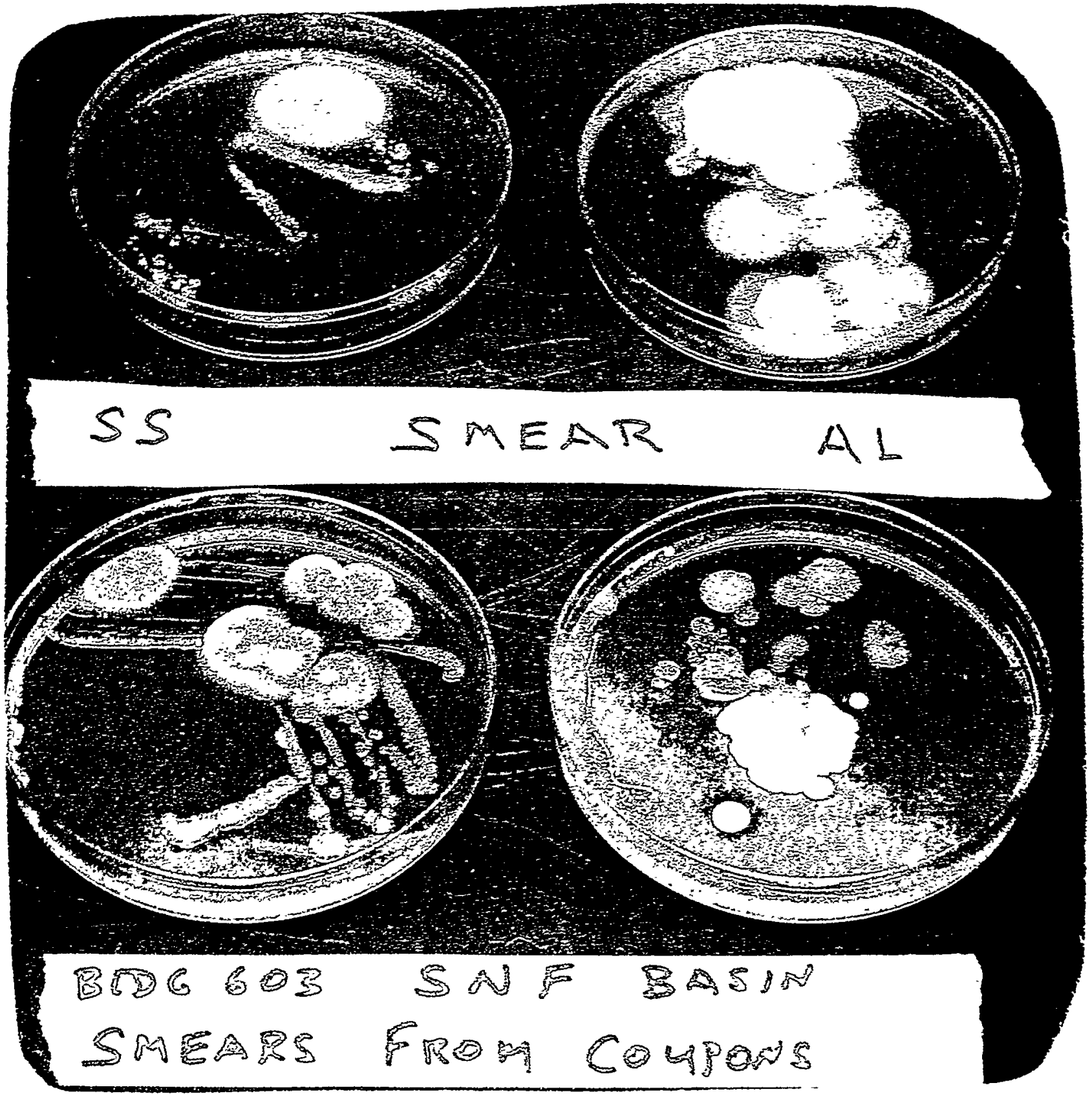

Figure 1. As shown in Figures 1 and 2, the acid producers have turned the selective $\mathrm{pH}$ media from red to yellow. This indicates that acid has been produced as a result of microbial growth on the plates (96-506-1-25). 


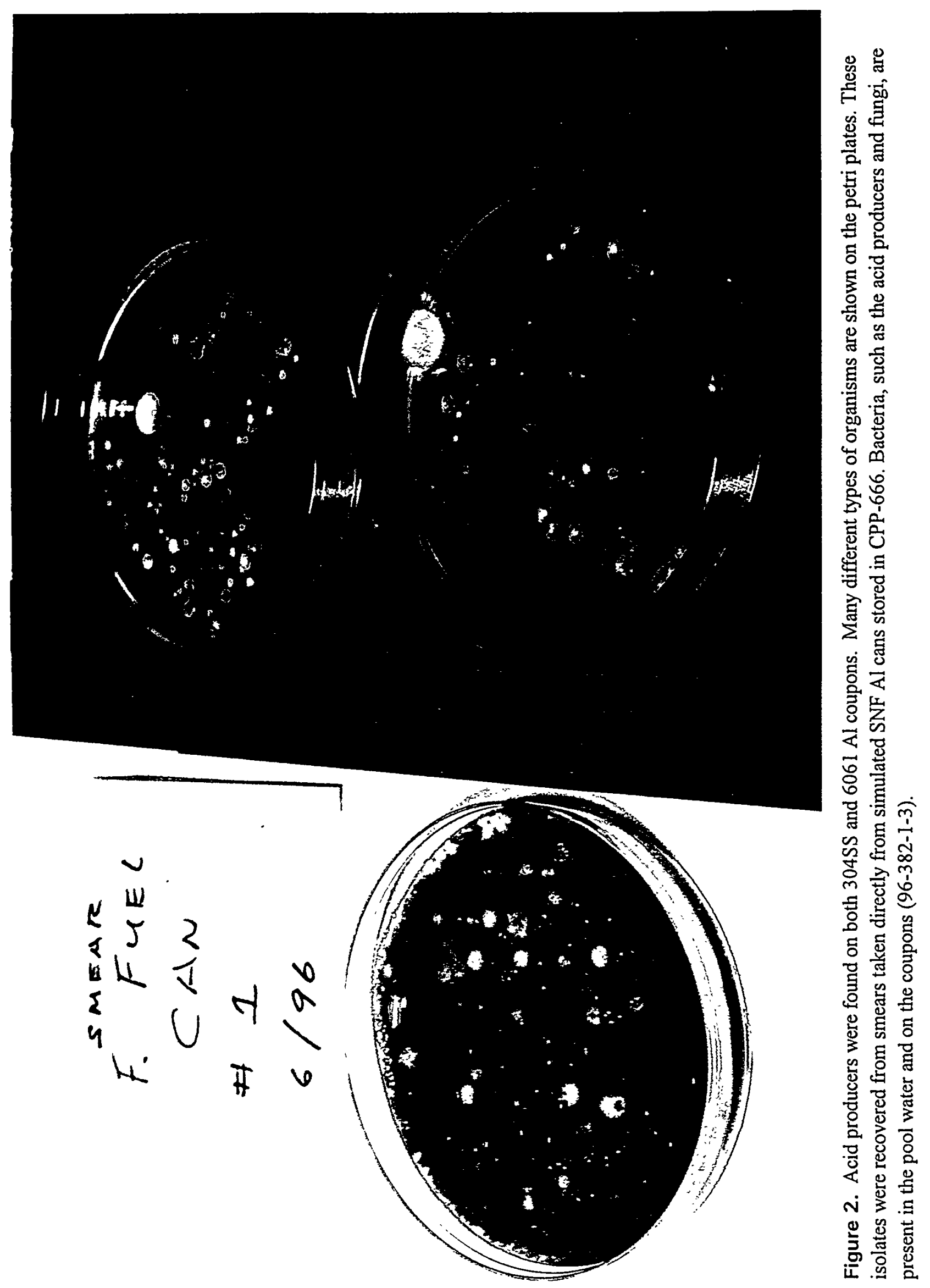




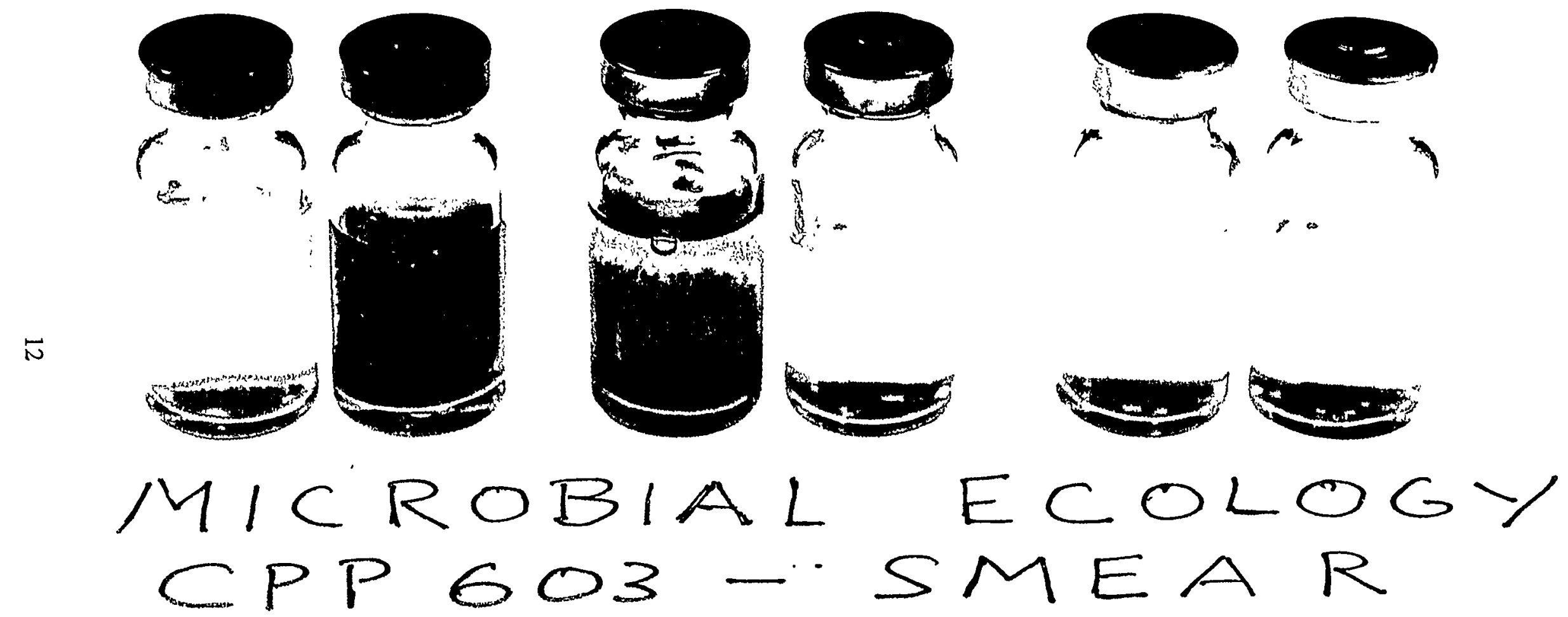

Figure 3. As shown in Figure 3, acid-producing bacteria are evident in the red-capped bottles that have changed from red (right bottle is the sterile control) to yellow. SRB are evident in the green-capped bottles that have changed from clear (right bottle is the sterile control) to black. General heterotrophic bacteria are seen as present in the gold-capped bottles by the level of turbidity (right bottle lacks turbidity). Comparison can be made between the sterile controls and the inoculated media (96-673-1-1). 


\section{ASSESSMENT OF MICROBIAL INFLUENCED CORROSION ${ }^{a}$}

\subsection{Presence of Biological Activity}

MIC is defined as corrosion initiated or accelerated by microorganisms. MIC is also known as biological corrosion, biologically influenced corrosion, biologically induced corrosion, microbial corrosion, microbiologically induced corrosion, and biocorrosion (Borenstein 1994). Susceptible materials of interest for the storage of SNF are Al, $304 \mathrm{SS}$, carbon steel, and copper-based alloys. In the power industry, corrosion studies have focused on condensers and service water systems where slime, barnacles, clams, and other macro-organisms are easily detected. Efforts have been made to eliminate the effect of these organisms through the use of chlorination, backflushing, organic coating, or thermal shock. The objective is to maintain component performance (i.e., fuel integrity with the SNF) by eliminating biofouling and reducing metallic corrosion. Recently, corrosion of power plant components by micro-organisms (bacteria) has been identified even in very clean systems. Active microbial metabolism, whether maintenance or growth, always requires at least water vapor such as atmospheric humidity (Horn and Meike 1995). This is of importance for the storage of SNF because if the dry cans can be made truly dry, the implication is that the microbial presence would be greatly reduced. Data are needed on whether storage cans exposed to air and humidity will sustain microbial activity.

Microbes exist in a variety of conditions. The resistance of microbes to high radiation fields is of particular interest to the SNF industry. The resistance of microbes to gamma radiation varies. Bacterial spores are relatively radiation-resistant; $3-4 \mathrm{kGy}\left(3\right.$ to $4 \times 10^{5}$ rads) of irradiation is required to effect a $90 \%$ kill, while most vegetative (non-sporulated) cells require only one-tenth of this dosage to effect the same percentage kill. However, there are species of bacteria that display much greater radiation resistance even in the vegetative state, including Micrococcus radiodurans, which can tolerate $10 \mathrm{kGy}\left(1 \times 10^{6} \mathrm{rads}\right)$ of irradiation without any effect on the viable cell count. It has also been shown that when they are contained in bentonite buffer material, it requires up to $1.3 \mathrm{kGy}\left(1.3 \times 10^{5} \mathrm{rads}\right)$ of irradiation to effect a 10 -fold decrease in viability of spores of the common soil bacterium, Bacillus subtilis and the radioresistant Acinetobacter radioresistens. Viable organisms have been isolated out of the damaged TMI reactor vessel (Sinha et al. 1990).

Biofilms are formed as a result of the colonization of metallic surfaces by microbes. The presence of biofilms or microbial slime masses on the surface of the metal is the first and most common indication of bacterial activity. The formation and activity of bioflims of bacteria on metal surfaces is closely associated with MIC. Microorganisms produce specific chemistries that are corrosive and specific environments that produce electrochemical reactions. These conditions lead to localized corrosion. The presence microbial activity on the surface of 304 SS can catalyze certain chemical reactions which encourage the coaccumulation and concentration of aggressive ions such as chlorides and intermediate sulfur compounds, e.g., sulphides. Pit initiation depends on the microbial activity, but pit propagation, specifically in 304 SS, may be independent of the microbial activity.

a. See Bibliography for several references on the general aspects of corrosion. 


\subsection{Types of Microbes}

Microorganisms exist as aerobes, or anaerobes. Within a biofilm, many different types of microorganisms can form synergistic communities that conduct combined processes that individual species cannot. Furthermore, a single microorganism can simultaneously affect corrosion via several mechanisms. Several types of microbes and their potential action on metallic surfaces are listed below.

\section{Sulfate Production}

SRB are of particular concern within wet storage of SNF. When conditions around storage containers become wet, cool, and anoxic, microbial activity is possible in the immediate vicinity of the storage containers. If the abiotic zone is repopulated, SRB are expected to dominate the micro flora, and SRBinfluenced corrosion might be possible under the biofilm (Little and Wagner 1996). However, the most aggressive corrosion of metals and alloys in the presence of SRB is observed when there are successive, alternating aeration-deaeration shifts.

\section{Acid Production}

Most heterotrophic bacteria produce organic acids during fermentation of organic substrates. The acids produced depend on the type of microorganisms and available substrate molecules. Acids may force a shift in the tendency for corrosion to occur (Little and Wagner 1996). The impact of acidic metabolites is intensified when they are trapped at the biofilm-metal interface. Acid-producing bacteria can promote electrochemical oxidation of a variety of metals by removing or preventing the formation of an oxide film.

\section{Ammonia Production}

Many organisms produce ammonia from the metabolism of amino acids or the reduction of nitrite or nitrate. In solution, ammonia forms $\mathrm{NH} 4+$ that can react with metal surfaces. This $\mathrm{NH}^{+}$formulation will change the $\mathrm{pH}$ on the surface and will then be a significant factor in $\mathrm{Al}$ corrosion.

\section{Metal Deposition}

Metal-depositing organisms create an environment that is conducive to corrosion. Dense deposits of cells and metal ions create differential aeration cells that effectively exclude oxygen from the area immediately under the deposit. Underdeposit corrosion is very important because it initiates a series of events that are individually or collectively extremely corrosive. Under these circumstances, pitting involves the conventional features of differential aeration, a large cathode-anode surface area, and development of acidity and metallic chlorides (Little and Wagner 1996).

\section{Hydrogen Production}

Walch and Mitchell (1983) proposed the following roles for microorganisms in hydrogen embrittlement of metals: (1) production of molecular hydrogen during fermentation, which may be dissociated into atomic hydrogen and absorbed into metals; (2) production of hydrogen ions via organic or mineral acids, which may be reduced to form hydrogen atoms at cathodic sites; (3) production of hydrogen sulfide, which stimulates 
absorption of atomic hydrogen into metals by preventing its recombination into hydrogen molecules; and (4) destabilization of metal oxide films.

Several classes of microorganisms can contribute to the occurrence of MIC, including fungi, algae, and bacteria. Fungi and algae may colonize metal surfaces and assist in the growth of corrosive bacteria. Each type of bacteria can be responsible for corrosion of many different metals. Also, many of these bacteria can work together to corrode metal surfaces (see Table 1).

\subsection{Mechanisms of Microbial Corrosion}

Research investigations and field case histories on MIC indicate that the localilized corrosion can be explained in terms of chemical and electrochemical reactions. One conclusion from these studies is that there is not a single mechanism that explains all of the MIC-related corrosion on different materials. The diversity of microbial types and metabolic pathways allows for a multi-mechanism explanation for MIC. For instance, some anaerobic organisms produce the very aggressive sulfide ion while aerobes and other anaerobes can produce organic acid species (Pope 1984). In addition to microbial diversity, the ability to form biofilm permits electrochemical reactions to occur between different areas on the surface of the metal.

The mechanistic steps of microbial corrosion are:

1. Absorption of nutrients (including oxygen) by microbial growths adhering to metal surfaces.

2. Utilization (uptake and biochemical transformation) of various substances that can result in alteration of the physical or chemical properties of the environment in deleterious ways.

Table 1. Types of bacteria that directly cause corrosion in metals.

\begin{tabular}{lll}
\hline \multicolumn{1}{c}{ Bacterium } & \multicolumn{1}{c}{ Action } & \multicolumn{1}{c}{ Problem } \\
\hline $\begin{array}{l}\text { Gallionella } \\
\text { Crenothrix } \\
\text { Spaerotilus }\end{array}$ & $\begin{array}{l}\text { Convert soluble ferrous ions to } \\
\text { insoluble ferric ions }\end{array}$ & $\begin{array}{l}\text { Produces iron oxide deposits } \\
\text { Increases corrosion }\end{array}$ \\
Desulfovibrio & Hydrogen sulfide producers (sulfate- & $\begin{array}{l}\text { Corrodes metals } \\
\text { Reduces chromates } \\
\text { Clostridium }\end{array}$ \\
oxiobacillus & & $\begin{array}{l}\text { Destroys chlorine } \\
\text { Precipitates zinc }\end{array}$ \\
& & Corrodes metals \\
Thiobacillus & Sulfuric-acid producer & Corrodes metals \\
Nitrobacter & Nitric-acid producer &
\end{tabular}


3. The result of the metabolic processes yields the following:

(a) The production of surface active substances

(b) The production of sulphuric acid by certain species of the sulphur oxidizing bacteria

(c) The production of organic acids

(d) The production of sulphide ions by SRB

(e) The possibility of the concentration of anions such as $\mathrm{S}^{\mathbf{}}$ and $\mathrm{Cl}^{-}$.

4. Interference with the cathodic process in the absence of oxygen by the sulphate-reducing bacteria.

\subsection{Biofilms}

Biofilms are formed when microorganisms attach to surfaces. Microorganisms on surfaces produce polymers and form gel matrices of bacterial exopolymers important to the structural integrity of biofilms. These films are a result of the production of extracellular materials, which are polysaccharides and proteins.

Biofilms perform several functions vital to microbial colonization of surfaces and survival of its constituent organisms. For example, the biofilm polysaccharide anchors microorganisms to the surface, traps nutrients from the bulk solution, and releases nutrients to the bacteria. Antagonistic molecules (biocides, surfactants, antibiotics, etc.) are captured and retarded by the anionic fibers of the exopolysaccaride. The biopolymer also shields the bacteria from predators, bacteriophages, and immune system factors. Exopolymers are acidic and contain functional groups that concentrate metal ions to form metal concentration cells. In addition, some organisms can derive all their electrochemical energy requirements from the oxidation of sulfur or iron and reproduce by fixing carbon dioxide.

When biofilms develop on metallic surfaces, they can create microenvironments conducive to corrosion (see Figure 4). The presence of adjacent microcolonies of different types of bacteria contributes to localized conditions. It has been demonstrated that these colonies can produce measurable potential differences at different points on the surface (Characklis 1991).

Another possible corrosion mechanism is due to incomplete biofilm coverage where the formation is non-uniform over a surface. This could also lead to potential difference between covered and uncovered areas.

Organic acids that are potentially corrosive are produced by some microorganisms under biofilms. The different species actively support one another. For example, a mixed microbial slime in a cooling system has certain rapidly growing microorganisms with a high demand for oxygen, with the result that the lower layers receive no oxygen, favoring the growth of anaerobic organisms such as SRB, which produce the highly corrosive agent hydrogen sulfide.

General and localized pitting corrosion is stimulated by the production of inorganic and organic acids during the metabolism of certain microorganisms (Tiller 1983). The ecosystems and the chemistry contained in the bacterial exopolymers can also encourage stress corrosion cracking and hydrogen embrittlement. 


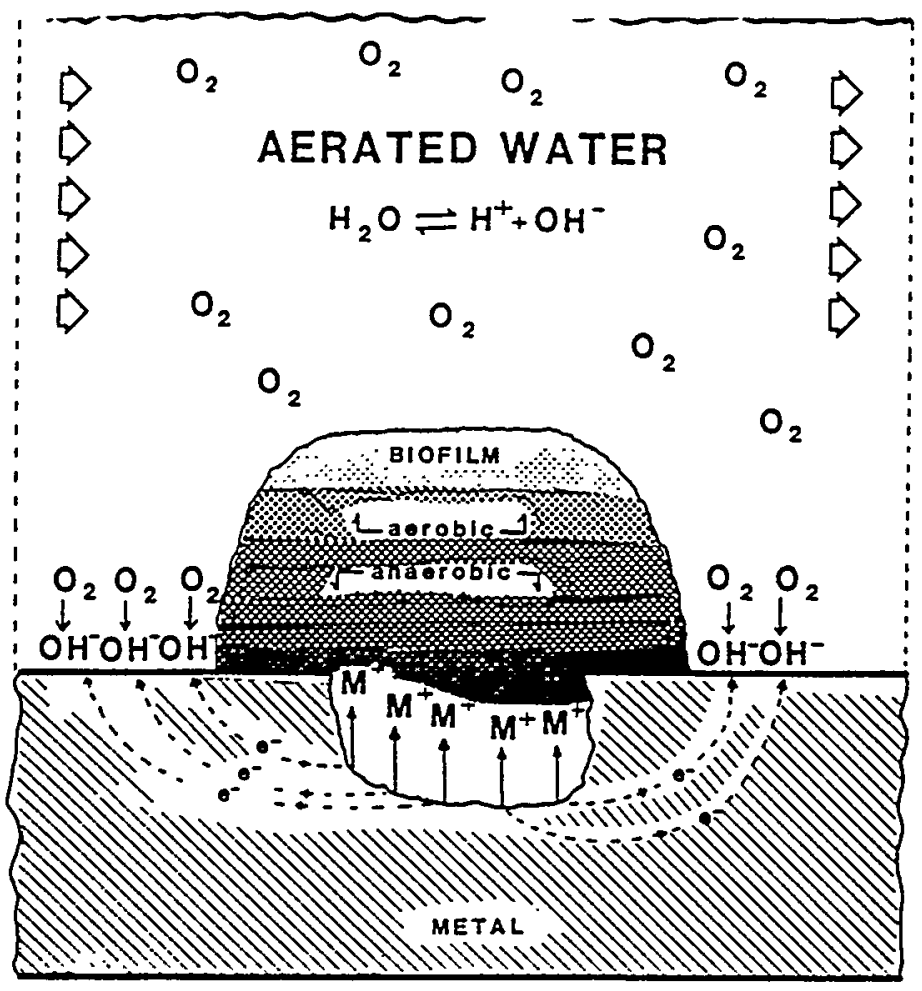

Figure 4. Biofilm.

Microbial fouling films affect the corrosion behavior of passive metals in natural waters and influences localized corrosion initiation and propagation. The microbial films shift the open circuit corrosion potential (OCP) of passive metals and enhance the kinetics of the cathodic oxygen reduction reaction (Dexter 1996). Physically, biofilms act as a diffusion barrier, tending to concentrate chemical species produced at the metal film interface and to retard diffusion of species from the bulk water towards the metal surface.

The presence within the biofilm of aerobic species capable of hydrocarbon degradation and subsequent fermentative metabolism will provide an oxygen-depleted area within the deeper layers of the biofilm. The aerobic species will supply suitable carbon and energy nutrients to support SRB, sulphidogenesis, and consequent MIC. Patchy or colonial growth can stimulate corrosion by the creation of oxygen concentration or differential aeration cells, the anaerboic area under the biofilm being anodic, and the site of metal loss (Dowling et al. 1990).

The stages of biofilm development are shown in Figure 5: (1) conditioning film accumulates on submerged surface; (2) planktonic bacteria from the bulk water colonize the surface and begin a sessile existence by excreting exopolymer that anchors the cells to the surface; (3) different species of sessile bacteria replicate on the metal surface; (4) microcolonies of different species continue to grow and eventually establish close relationships with each other on the surface, the biofilm increases in thickness, and conditions at the base of the biofilm change; (5) portions of the biofilm slough away from the surface; and (6) the exposed areas of the surface are recolonized by planktonic bacteria or sessile bacteria adjacent to the exposed area. 

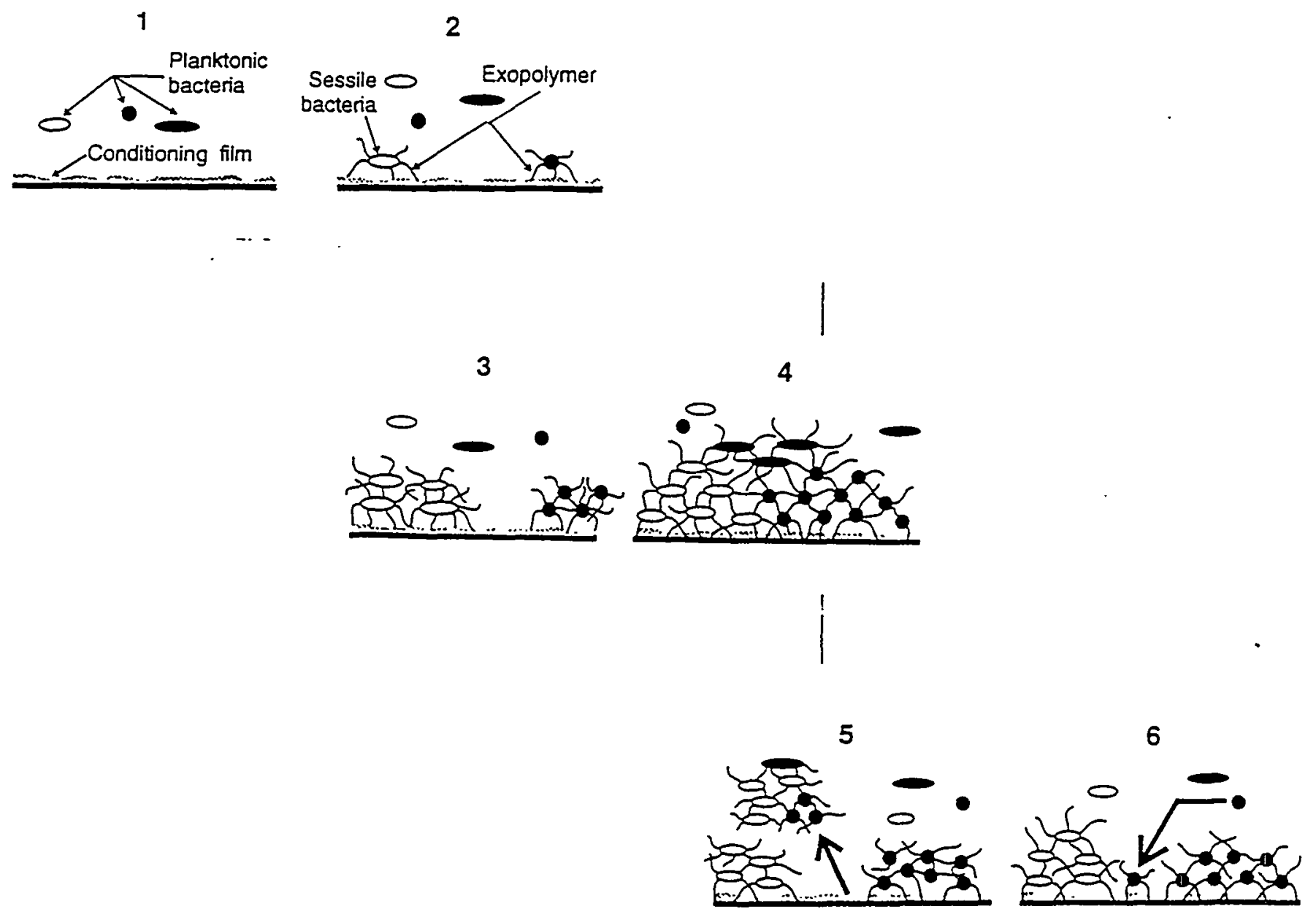

Figure 5. The stages of biofilm development.

\subsection{Impact of Drying on Biofilms and MIC}

Microorganisms can withstand extremes in dehydration; for example, the yeast cells packaged for commercial use are taken down to dryness and have a binder added to prevent caking. A standard method for maintaining a culture for long periods of time is to process it by freeze drying and storing at $-80^{\circ} \mathrm{C}$. What is of interest is what activity level exists at different levels of hydration. Although viable cells can be recovered from desiccated biofilms, there are data gaps regarding the activity of the cells in desiccated biofilms. However, in porous media such as soils, microbial activity does exist down to very low levels of moisture content.

\subsection{Case Studies}

\subsubsection{Aluminum}

Case 1: Corrosion of an Al surface while in air was observed to be caused by bacterial activity (Sakurai et al. 1995). The bacteria accumulated within the cell in a granular form. This was determined 
to be from a very common bacterium Alcaligenes Denitrificans. The analysis showed that the bacteria can be active and accumulate $\mathrm{Al}$ even without water but with ambient humidity. Several metallic and nonmetallic elements such as $\mathrm{Fe}, \mathrm{Cl}, \mathrm{S}, \mathrm{Si}, \mathrm{Mg}$, and $\mathrm{Al}$ form particles that seem to be bound to the surface of the bacterial cell. The observed corrosion of the surface could be prevented by illuminating the area with ultraviolet rays.

Case 2: The fungus Cladosporium resinae is believed to be the main organism responsible for the corrosion of $\mathrm{Al}$ and its alloys in fuel/water systems (Videla 1986). The metabolic activity of $C$. Resinae is accomplished through the oxidation of hydrocarbon chains to organic acids. Microbial fixation points become the nucleation center for pitting.

Case 3: A heat exchanger was used in a DOE demonstration home at Oak Ridge. The heat exchanger was used to exchange energy between a methanol/water (brine) solution and relatively pure potable water. After 4 months of service, the heat exchanger failed due to pitting attack from the tap water side. Direct and cultured microbial counts of samples taken from the corroded area ranged from 1 $\times 10^{6}$ to $1 \times 10^{7}$ bacteria $/ \mathrm{mL}$. The species of bacteria responsible for the corrosion were not identified, but their overall effect was to form a slime on metal surfaces, raise the $\mathrm{pH}$ of the water to 9.5 , and cause pitting of the $\mathrm{Al}$ heat exchanger. Metallurgical examination of the pitted areas showed a 'faceted' attack as shown in Figure 6. This faceted attack is consistent with MIC. After the failure occurred, the heat exchanger was replaced, a system water purge was conducted, a borate-silicate corrosion inhibitor was added, a biocide was added, a corrosion monitoring program was initiated, and microbiological samples were taken from the water every 3 months. These precautions provided sufficient protection as no additional corrosion problems were reported (Schmitt 1986).

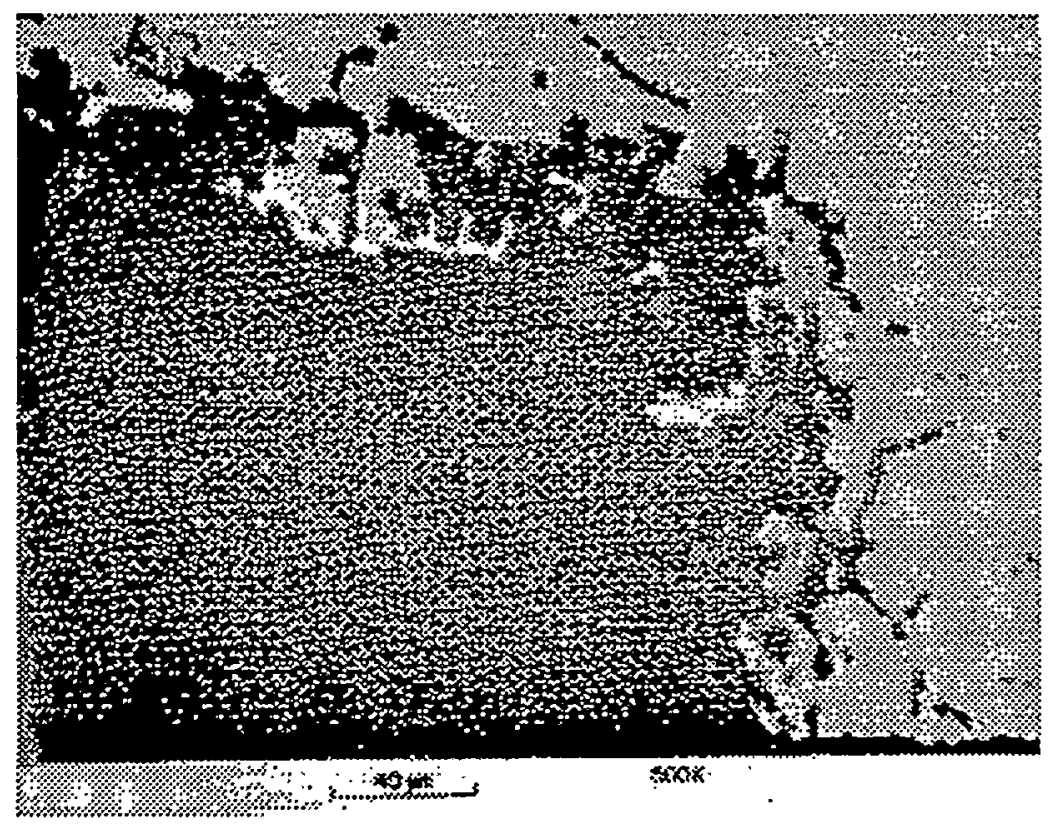

Figure 6. Scanning electron micrograph of Al sample exposed to tap water for four months. The faceted corrosive attack is consistent with MIC. 
The susceptibility of $\mathrm{Al}$ and its alloys to localized corrosion makes it particularly vulnerable to MIC (Little and Wagner 1996). In one case study, after 12 months, both Al 1100 (commercially pure Al) and Boral (a composite with a layer of boron carbide dispersed in $\mathrm{Al}$ and sandwiched between two sheets of $\mathrm{Al}$ 1100) showed pitting with accumulation of corrosion products in and over pits after exposure to organisms isolated from the TMI nuclear reactor vessel. Al 1100 also showed signs of MIC.

MIC was demonstrated on $\mathrm{Al} 1100$ and $\mathrm{Al} 6061$ after a few weeks exposure to deionized water in a storage basin (Kalaiyappan et al. 1995).

Experimentation results on dry storage capability are reported in $A$ Corrosion Product Identification and Relative Rates of Corrosion Candidate Metals in an Irradiated Air Steam Environment (Reed et al. 1990). Experiments were performed at dry air, $15 \%$ relatively humidity (RH), and $100 \% \mathrm{RH}$. The extent of corrosion was strongly dependent on the moisture content of the gas phase.

Simpson (1986) raises the similar point by mentioning two potential dry storage problems: (1) the possibility of failure of the dry storage container allowing damp air to replace dry argon cover gas, and (2) the possibility of water-logged, failed fuel being inadvertently containerized, giving rise to a humid argon atmosphere within the dry storage container. More data are needed to understand the synergistic effect between radiolysis and bacteria.

\subsubsection{Stainless Steel}

The hydrotesting of two 8-in. diameter pipelines with potable water (chloride $<50 \mathrm{ppm}$ ) was seen as the cause of leaks discovered in several butt welds. The water had been allowed to drain out and had not been dried (Tiller 1983). An on-site internal visual examination of a number of affected areas revealed rust-colored staining and streaking on the walls of the pipes, particularly around the defect areas in the welds. A radiographic survey of all butt-welds showed that many more were affected, but these had not yet achieved through-wall penetration. A subsequent microscopical examination of the defects showed bottle-shaped sub-surface cavities beneath the welds. An in situ $x$-ray analysis of the pits identified large quantities of iron and chromium, the presence of organic material. Significant levels of sulfur but no appreciable chloride was detected. Chemical analysis of residual water from the pipe showed that it had a $\mathrm{pH}$ of 7.2 and contained $25 \mathrm{ppm}$ of chloride, and analysis of debris confirmed the presence of manganese. During the metallurgical examination, water exuded from the subsurface cavities, and these registered a $\mathrm{pH}$ of between 2 and 3.

An optical microscopical examination of samples of water taken from the pipe and from the fire main were found to be microbially active. SRB were positively identified, although the old samples from the pipe contained dead and senescent cells. In addition, there were a number of filamentous bacteria in large clusters surrounded by a light brown colored corrosion product. A subsequent microbial assay confirmed the presence of both SRB and the iron bacterium, Gallionella. The case for pitting attack due to chloride ions is doubtful because chloride contents of the test water, the residual water, and the corrosion debris were all low. It was also noted th.st a umber of the affected welds had not been flooded for the exposure period (18 months). The presence of urganic material and sulphide in the pits, however, indicates that microorganisms may have been involved in the attack. An explanation solely in terms of microbial involvement is difficult, but it would appear that there is some evidence to indicate their possible 
participation. It is probable that no single mechanism is totally responsible for the failures, and a likely combination is that pit initiation occurred during the hydrotest period at defects in oxidized welds or at areas that contained physical defects such as porosity, over penetration, etc., and that propagation was assisted by the alternate action of the sulfur-reducing and iron-oxidizing bacteria present in the residual water after hydrotest. Further propagation occurred due to acidic pit conditions without the need for further bacterial action.

MIC has caused localized corrosion problems in several treated water 304 SS systems in the nuclear power industry. Rates of corrosion were estimated to vary from 1.5 to $13 \mathrm{mils} / \mathrm{yr}$ and in one case with penetration of the wall in 1.5 years (Sinha et al. 1990). 


\section{MIC POTENTIAL IN SNF STORAGE}

\subsection{Issues in Remaining Wet Storage}

\subsubsection{Hanford}

The plan for the Hanford Site SNF stored at the K-East and K-West basins is to remove it from the basins, dry it, and place it in dry storage on an accelerated basis. The schedule calls for the initial fuel movement from the K-West Basin to occur in December 1997.

These basins have experienced accelerated corrosion rates due to poor water quality. They have experienced pitting corrosion of $\mathrm{Al}$ fuel storage canisters that was attributed to $\mathrm{Cu}$ and $\mathrm{Cl}$ ions. The copper was introduced into the basin water through corrosion of copper based alloy heat exchangers from the addition of biocides (chlorine gas, sodium hypochlorite, calcium hypochlorite). The $\mathrm{N}$-reactor fuel has suffered localized corrosion of the uranium metal fuel through breaks in the zircalloy cladding. The $\mathrm{Cl}^{-}$ ions from the biocide additions will also affect the Al pitting.

The possibilities for MIC damage to fuel and storage devices at these pools cannot be determined. Although the given reason for the decrease in water quality was attributed to biocide addition, there are no data given on evaluation or measurement of MIC in the fuel inspection program.

The water quality improvements in the K-East and $\mathrm{K}$-West basins has greatly reduced the general corrosion rates of the various materials. Based on these rates, it is anticipated that there are no major water storage concerns that have to be dealt with before the fuel is moved.

\subsubsection{INEL}

The plan for the INEL is to move all remaining fuel in the CPP-603 South Basin to dry storage by FY 2000 to 2006. The Al and stainless clad fuels stored in CPP-666 will be moved by FY 2000 to 2006 also.

The poor water quality in CPP-603 will continue to degrade the Al-clad fuels. The sampling program for biological activity has measured SRB and acid producing bacteria. These microbes will accelerate the corrosion of $\mathrm{Al}$ because of the attachment of the biofilms to the surface.

Corrosion inspections of the $\mathrm{Al}$ sample ( $\mathrm{Al}$ dummy can) has shown through-wall pitting in 4 years or less. The water quality of the CPP- 666 basin is high with conductivity of less than 2 micro-siemens $/ \mathrm{cm}^{2}$ This water quality is considered to be non-aggressive to Al-clad SNF. There is a significant quantity of $\mathrm{Al}$ fuel stored in pool 6 of CPP-666. The observed pitting mechanism needs to be understood to evaluate if this remaining fuel is in danger of accelerated pitting that would severely damage the fuel as has happened in CPP-603. The potential of favorable conditions for additional corrosion exist since some of the CPP603 fuel is being moved into CPP-666 as well as the FRR fuel. 
At the INEL, there are 3,600 304 SS fuel cans storing EBR-II fuel in the FAST facility. The threaded seals at the top of these cans are considered susceptible to MIC and crevice corrosion with the potential of water being introduced and reacting with the uranium fuel meat.

\subsubsection{SRS}

The Al-clad fuel at the SRS Fuel Storage Basins will be stored longer than at the INEL or Hanford $\mathrm{K}$-Basins. It is anticipated that the fuel will be moved to dry storage by FY 2006.

There have been corrosion upsets in the past (Howell 93, 94, etc.) that have been attributed to poor water quality. The water quality in these basins has been improved as described in various reports (Howell for example), and it is felt that these measures will mitigate any further chance of accelerated corrosion.

The pitting on Al-clad fuel at SRS has been investigated through a metallurgical failure analysis performed in a hot cell (Howell 1993, Nelson and Howell 1995). It should be noted that this analysis did not report any evaluation of microbiological involvement in the pitting process. The standard metallographic preparation techniques will destroy all evidence of a microbiological component.

\subsubsection{General Observations-Aluminum and Stainless Steel}

There are several important implications as a result of having biofilms on surfaces either in wet or dry storage conditions for the SNF. As the authors ${ }^{b}$ toured the sites, almost all knowledge operations personnel indicated that microbial problems existed sometime in the basins. The main concern then was the clarity of water that was disrupted by these small microscopic living entities. In order for water quality to deteriorate to an extent that visibility is impaired depends on several factors, e.g., depth of viewing field, light intensity, size of organisms, and number of organisms). However, a population of $10^{4}-10^{6}$ cells $/ \mathrm{mL}$ is required to significantly cause water turbitiy problems. Most basin waters have had their water clarity restored to an acceptable level. However, what has been overlooked for too long of a time is that now and in the past, a biofilm has developed on basin surfaces. The surface attachment has extended itself to include fuel, fuel cladding and assemblies, and operational equipment such as racks. The following consequences of this attachment as substantiated in the literature (Borenstein and Lindsay 1994; Kobrin 1993) as well as our own and that of SRS (to a small degree) is that MIC often occurs and expresses itself as localized corrosion. The questions that have not been addressed nor can be answered at this time are the following:

- To what degree is MIC participating in all the corrosion observed in the basins?

- Since microorganisms have been shown to exist in all of the pools at some time and more recently shown to be present in INEL CPP-666 and 603 and in SRS RBOF, what corrosive properties does this community have? Do some communities in these basins pose more of a concern than others?

b. See Appendix C for Trip Reports. 
- The INEL work on Al corrosion has shown that pits are occurring in coupons and in the dummy cans with through-wall penetration in 4 years in good quality water. No corrosion products were observed; a biofilm has been confirmed, but has not had bacterial colonies directly correlated with pits. Why are there no corrosion products such as has been observed in other basins? Is this a different type of corrosion or at least a different causative agent? Does the biofilm play a role in this pitting? What influences the rate of this type of pitting, especially since the water chemistry is thought to be excellent quality?

- Our recent microbial survey of coupons in CPP-603 has produced positive results for SRB and acid-producing bacteria. What impact will their presence have on the fuel transferred to CPP666 and on the fuel already in CPP-666? What impact will their presence have on the materials left in CPP-603? This is a concern when considering the fuel movement activities that have been ongoing in CPP-603. The presence of SRB and acid-producing bacteria in the basin can increase the microbial activity.

- What synergism exists between MIC and other causative corrosive agents, conditions, and processes, e.g., galvanic, stagnant water, surface damage due to fuel movement, and the addition of different microbial communities?

- What implications will follow the fuel as it is interned into dry storage as a result of the attached, biofilm/corrosion products, biofilm/sludges, etc.? Known facts are that microbes cause corrosion under atmospheric conditions (unsaturated vapor), biofilms aid in resisting desiccation, biofilms concentrate inorganic species, some of which can be aggressive agents for the propagation of pits, etc.

The Sourcebook for Microbiologically Influence Corrosion in Nuclear Power Plants, (Licina 1988) discusses the corrosion of 18-8 SS due to MIC attack. The nuclear power plants have high-purity aqueous environments such as is needed in the reactor coolant system, emergency systems, reactor auxiliary systems, the feedwater train, and condenser. MIC has caused the early replacement of these systems, which has caused additional cost and time delays. Heat exchanger tubing made of Alloy 800 , a superaustenitic SS, was assumed corrosion resistant to fresh water. The tubing experienced through-wall pitting in less than 2 years of service (Sinha et al. 1990).

\subsection{Impact on Storage Drying Process}

Drying Studies of Simulated DOE Aluminum Plate Fuels (Lords et al. 1996) discusses ongoing drying procedures being done at the INEL. Researchers found that residual moisture contained within hydrated corrosion products between the fuel plates may be difficult to remove during normal drying practices due to the tenacity of the chemically bound waters of hydration. Any remaining moisture may lead to additional degradation of the fuel and canister materials and eventual buildup of excess pressure in a sealed storage system. The preferred method of remotely determining if the free water has been removed is to monitor the pressure inside the drying chamber while drying. Once the pressure stays below 3 torr, the canister can be assumed to be dry. However, for fuels containing hydrated materials, the moisture is only gradually liberated during the vacuum drying process. This reaction is very slow at ambient temperatures, and enough moisture remains physically or chemically bound to the hydrated material to obscure the 
vacuum drying endpoint. Vacuum drying does not remove bound water corrosion product between the plates in Al-clad plate fuels. Table 2 shows data for drying a simulated corroded Al plate fuel element under several variations of proposed drying procedures. This table shows how allowing biofilm accumulation and corrosion in wet storage impacts the operational cost of transferring the fuel for dry storage.

\subsection{Dry Storage Degradation Issues}

This section will not address long-term repository issues. The literature search did not reveal any reports that document the performance of Al-clad or 304 SS SNF in dry storage. Guenther et al. (1996) cites data on zircaloy in dry storage and reports no significant problems.

\subsubsection{Hanford Site}

The materials degradation issues that will be involved in the drying and packaging of the SNF located (Zircaloy-2, Al) in the K-East and K-West basins are described in Johnson (1995). Other problems such as pyrophoric risk, sludge drying, and release of radioactive species overshadow the contribution of microbes to the corrosion process. Due to the fact that the corrosion excursions in these basins were caused by biocide additions, it may be possible that MIC was a contributor to the observed corrosion. However, sampling for the presence of microbes on corroded areas was not done. The general issue of dry storage of Zircaloy clad fuel storage has been addressed (Guenther et al. 1996). The MIC issues that will occur with Al-clad Hanford fuel will be addressed in the following INEL and SRS sections.

\subsubsection{INEL}

The most vulnerable fuel at the INEL is the Al-clad ATR research reactor fuel elements that are stored at both CPP-603 and 666. Previous inspections have shown that the cladding has been thinned with corrosion pitting from reactor operation (Lundberg 1994). The underwater corrosion inspection at CPP603 has shown mechanical damage and indications of pitting corrosion (with voluminous corrosion

Table 2. Average results from various drying procedures.

\begin{tabular}{lccccccc}
\hline $\begin{array}{l}\mathrm{V}=\text { Vacuum time } \\
\mathrm{H}=\text { Heating time }\end{array}$ & $\begin{array}{l}\mathrm{V}=0.5 \mathrm{hr} \\
\mathrm{H}=0 \mathrm{hr}\end{array}$ & $\begin{array}{l}\mathrm{V}=2 \mathrm{hr} \\
\mathrm{H}=0 \mathrm{hr}\end{array}$ & $\begin{array}{l}\mathrm{V}=4 \mathrm{hr} \\
\mathrm{H}=0 \mathrm{hr}\end{array}$ & $\begin{array}{c}\mathrm{V}=6 \mathrm{hr} \\
\mathrm{H}=0 \mathrm{hr}\end{array}$ & $\begin{array}{l}\mathrm{V}=2 \mathrm{hr} \\
\mathrm{H}=2 \mathrm{hr}\end{array}$ & $\begin{array}{l}\mathrm{V}=4 \mathrm{hr} \\
\mathrm{H}=2 \mathrm{hr}\end{array}$ & $\begin{array}{l}\mathrm{V}=6 \mathrm{hr} \\
\mathrm{H}=2 \mathrm{hr}\end{array}$ \\
\hline $\begin{array}{l}\text { Weight percent change of } \\
\text { simulant after drying, \% }\end{array}$ & $10 \%$ & $11 \%$ & $18 \%$ & $18 \%$ & $29 \%$ & $39 \%$ & $40 \%$ \\
$\begin{array}{l}\text { Estimated total water in } \\
\text { simulant, } \mathrm{B}\end{array}$ & 414 & 444 & 387 & 405 & 405 & 389 & 335 \\
$\begin{array}{l}\text { Estimated total water } \\
\text { removed from simulant, } \mathrm{l}\end{array}$ & 66 & 77 & 108 & 114 & 114 & 239 & 208 \\
$\begin{array}{l}\text { Estimated weight percent of } \\
\text { water removed from simulant } \\
\text { after drying, \% }\end{array}$ & $16 \%$ & $17 \%$ & $28 \%$ & $28 \%$ & $28 \%$ & $61 \%$ & $62 \%$ \\
\hline
\end{tabular}


products) obscuring the ATR elements. These video inspections can look at only the top exterior of the fuel element and can't assess the condition of the fuel element inside the fuel element assembly. The elements being moved out of CPP-603 then have mechanical damage, possible pitting corrosion damage and a desert dirt/corrosion product mixture on and inside the fuel element plates. This physical condition will cause fuel element drying problems as discussed by Lords et al. (1996).

The INEL has started corrosion testing of canister storage materials (304 SS) and Al alloys in simulated dry storage corrosion environments. The materials are being tested in the laboratory and at the Irradiated Fuel Storage Facility (IFSF) (Ryskamp et al. 1996).

The SRTC has performed corrosion testing on simulated dry storage conditions for $\mathrm{Al}$ alloys used for fuel cladding (Peacock 1996; Howell 1996). The work investigated the effect of temperature and relative humidity on the high-temperature (up to $150^{\circ} \mathrm{C}$ ) corrosion of the $\mathrm{Al}$ alloys.

\subsubsection{LANL}

Los Alamos National Laboratory has been storing the Omega West Reactor fuel (ATR type) for up to 3 years with no visible degradation (personal communication from Larry Field-LANL). The LANL fuel will be moved to SRS for storage starting in January 1997. 


\section{CONCLUSIONS}

The Hanford K-East and K-West basins and the INEL CPP-603 Basin experienced corrosion rate excursions on SNF cladding and storage devices due to additions of chemical biocides and poor water quality.

The SRS Reactor basins experienced corrosion excursions due to poor water quality.

Various microbes that could affect the corrosion reactions have been identified in the SRS, INEL, and Hanford Basins.

The impact of transferring FRR fuel to our basins is unknown.

There has been no corrosion examinations that have performed the necessary biological studies to identify microbes that are taking part in the corrosion reactions.

Corrosion coupons from CPP-666 have shown microbial growth.

The microbial contribution to the corrosion of fuel elements in wet storage has not been determined.

The threat of microbial degradation of Al fuel in dry storage is unknown.

Biofilm formation on SNF wet storage pools and equipment lead to increased exposure to personnel during fuel transfer and will also lead to decreased water clarity. 


\section{RECOMMENDATIONS}

Hot-cell microbial and metallographic examinations should be made on representative samples of ATR fuel elements from CPP-603, ARMF/CRFMF, MTR, and CPP-666. The species of microbes would be identified. The effects of the identified microbes would be determined for pitting, and mitigation procedures to reduce these microbes would be proposed.

The microbial monitoring program of the SRS basin water in the RBOF and $\mathrm{K}$ and $\mathrm{L}$ Basins should continue.

Protocols for water quality should be developed in terms of microbial presence. This would include techniques for monitoring, mitigation, and prevention of biofilms on SNF.

The laboratory studies of MIC of Al-clad SNF should be continued at SRS and the INEL in order to determine what effects the microbes have on the Al plate fuel.

The dry storage corrosion tests at the INEL and SRS should be continued.

The dry storage corrosion tests at the INEL and SRS should assess MIC and biofilms impact on the drying process. An evaluation is needed on the role of microbial activity continuing in fuel channels in dry storage.

The dry storage behavior of the Omega West Reactor fuel should be assessed and documented in the first quarter of FY -97 before this fuel is sent to SRS for wet storage.

Laboratory studies should be performed to assess the impact of foreign research reactor fuels at SRS and the INEL.

Mitigation and prevention measures such as biocides and water quality treatment needs to be monitored.

Specific tasks are outlined in Appendix B. 


\section{BIBLIOGRAPHY}

South Texas Project 1 \& 2, Palo Verde 2 (PWR), WolfCreek (PWR), and North Anna 1 \& 2 (PWR), Institute of Nuclear Power Operations, 1983 \& 1984.

Aluminum, Vol. 1. Properties, Physical Metallurgy and Phase Diagrams, American Society for Metals, 1967.

Andrade, A., "Stress-Assisted, Microbial-Induced Corrosion of Stainless Steel Primary Piping and Other Aging Issues at the Omega West Reactor," Topical Seminar on Management of Aging of Research Reactors - Geesthacht, Germany, LA-UR-95-1618, 1995.

Ayllon, E. S. and Rosales, B. M., "Technical Note: Electrochemical Test for Predicting Microbiologically Influenced Corrosion of Aluminum and AA 7005 Alloy," Corrosion, Vol. 50, No. 8, 1994.

Blumenthal, W. B., The Chemical Behavior of Zirconium, D. Van Nostrand Company, Inc., Princeton, New Jersey, 1958.

Borenstein, S. W. and Lindsay, P. B., "MIC Failure Analysis," Materials Performance, pp. 43-45, April, . 1994.

Borenstein, S. W., Microbiologically Influenced Corrosion Handbook, Industrial Press, 1994.

Brundage, E. R., Wiatr, C. L. , and Smyrniotis, C.R., "Microbial Control in the Aluminum Industry," Proceedings of the 119th TMS Annual Meeting in Anaheim, CA, Feb 18-22, 1990.

Bryers, J. D. and Characklis, W. G., "Processes Governing Primary Biofilm Formation," Biotechnology and Bioengineering, vol. XXIV, pp. 2451-2476, 1982.

Caskey, G. R., "Materials Issues in Interim Storage and Direct Disposal of Aluminum clad SNF", WSRCTR-93-502, 1993, Aiken S.C.

Characklis, W.G., Little, B.J., Stoodley, P., McCaughey, M.S., "Microbial Fouling and Corrosion in Nuclear Power Plant Service Water Systems", Corrosion 91, March 1991

Cigna, R, Llewelyn Leach, J. S., and Nehru, A. Y., "The Corrosion of Zirconium and Zircaloy-2 at Low Temperatures," Journal of the Electrochemical Society, vol. 113, No. 2, pp. 105-108, February, 1966.

Costerton, J. W., Geesey, G. G. and Jones, P. A., "Bacterial Biofilms in Relation to Internal Corrosion Monitoring and Biocide Strategies,". Materials Performance, pp. 49-53, 1988.

Dexter, S. C., Duquette, D. J., Siebert, O. W., Videla, H. A., "Use and Limitations of Electrochemical Techniques for Investigating Microbiological Corrosion," Corrosion, vol. 47, no. 4, pp. 308-318, April, 1991. 
Dexter, S. C., "Biofouling and Biocorrosion," The Bulletin of Electrochemistry, 12(1-2) Jan-Feb 1996, pp. 1-7.

Dirk, W. J., Internal Company Letter DIRK-14-96 to C. J. Woolstenhume, "Results of Corrosion Coupons from MTR and ARMF/CRFMF Fuel Storage Canals," June 24, 1996.

Dirk, W. J., Internal Company Letter DIRK-34-94 to B. W. Carlsen, "Annual corrosion of CPP-666 Stainless Steel and Aluminum "Tie-Plate Specimens".

Dirk, W. J., "Corrosion in ICPP Fuel Storage Basins," paper No. 148, NACE Corrosion 94.

Dirk, W. J., Internal Company Letter DIRK-32-92 to J. E. Hevlow, “Annual Corrosion Inspection of Aluminum Corrosion Coupons in the CPP-666 Basin," September 3, 1992.

Dirk, W. J., Internal Company Letter DIRK-29 -93 to J. E. Hevlow, “Inspection of FERMI Mockup Fuel Can".

Dirk, W .J., Internal Company Letter DIRK-34-94 to B. W. Carlsen, "Corrosion Inspection of CPP-666 Manual Fuel Handling Tools".

Dirk, W. J., Internal Company Letter DIRK-23-95 to C. S. Olson, "Biennial Inspection of the FERMI Mockup Fuel Can".

Dowling, N. J., Mittleman, M. W., and Danko, J. C., Microbially Influenced Corrosion and Biodeterioration, October, 1990.

Escher, A. R and Characklis, W. G., "Microbial Colonization of a Smooth Substratum: A Kinetic Analysis Using Image Analysis,” Wat. Sci. Tech., vol. 20, no. 11/12, pp. 277-283, 1988.

Evans, U. R. and Edeleanu, C., "The Causes of the Localized Character of Corrosion on Aluminum," Transactions of the Faraday Society, vol. XLVII, pp. 1121-1135, 1951.

Frost, C. R, Naqvi, S. J., and McEachran, R. A., "Design Considerations and Operating Experience with Wet Storage of Ontario Hydro's Irradiated Fuel," Proceedings of the 1987 International Waste Management Conference in Hong Kong, November 19-December 5, 1987.

Guenther, R. J., Johnson, A. B., Lund, A. L., Gilbert, E. R., Pednekar, S. P., Berting, F. M., Burger, L. L., Bryan, S. A., Orlando, T. M., "Initial Evaluation of Dry Storage Issues for Spent Nuclear Fuels in Wet Storage at the Idaho Chemical Processing Plant", INEL-96/0140, July 1996.

Horn, J. M. and Meike, A., Microbial Activity at Yucca Mountain, Lawrence Livermore National Lab, UCRL-ID-122256, Sept., 1995.

Hoskins, A. P., Scott, J. G., Shelton-Davies, C. V., McDannel, G. E., "Fuel Performance in Water Storage," WINCO 1167, Nov 1993, Idaho Falls, ID. 
Howell, J. P., Corrosion of Aluminum Alloys in Wet Spent Fuel Storage, Savannah River Technology Center, WSRC-TR-95-0343, 1995.

Howell, J. P., Issues Related to the Potential for Microbiological Influenced Corrosion in the RBOF Fuel Storage Basin (U), SRT-MTS-95-0114, November 21, 1995.

Howell, J. P., Foreign Research Reactor Spent Fuel Storage (U), SRT-MTS-96-0047, May 9, 1996.

Howell, J. P., Zapp, P. E., and Nelson, D. Z., "Corrosion of Aluminum Alloys in a Reactor Disassembly Basin," Corrosion 93 - NACE, Paper No. 609, 1993.

Howell, J. P., Zapp, P. E., "Affect of Water Conductivity on Corrosion of Aluminum Alloys in Spent Fuel Storage," Corrosion 94 - NACE, Paper No. 118.

Howell, J. P., "Corrosion of Aluminum Clad Spent Fuel in Reactor Basin Water Storage," Corrosion 95, Paper 429, 1995.

Howell, J. P., "Corrosion of Aluminum-Clad Spent Fuel in Reactor Basin Water Storage," Paper 429, Corrosion 95, 1995.

Howell, J. P., "Durability of Aluminum Clad Spent Nuclear Fuels in Wet Basin Storage," Paper 128, Corrosion 96, 1996.

Howell, J. P., Burke, S. D., "The Corrosion of Aluminum Clad Spent Nuclear Fuel in Wet Basin Storage," Spent Fuel Storage Conference, Reno, Nevada, June 1996.

Howell, J. P. "Corrosion of Aluminum Clad Spent Nuclear Fuel in Wet Basin Storage," IAEA CRP Meeting Budapest, Hungary, August 7-9, 1996.

Huppatz, W., "Investigations into the Corrosion Behavior of Metallic Materials with Respect to Drinking Water. III. Aluminum," Werkst. Korros., 35, (12), 578-581, Dec. 1984.

Jain, D. K., "Microbial Colonization of the Surface of Stainless Steel Coupons in a Deionized Water System," Wat. Res., vol. 29, no. 8, pp. 1869-1876, 1995.

Johnson, A. B., Burke, S. P., "K Basin Corrosion Program Report", WHC-EP-0877, Westinghouse Hanford Company, Sept. 1995.

Kalaiyappen, C., Dirk, W. J., Wolfram, J., Geesey, G., "Impact of Microbial biofilm on the Corrosion of Nuclear Power Plant Stainless Steel and Aluminum Alloys", 1995, Bozeman MT.

King, R. A., "An Outline of 150 Man-Years of Microbial Corrosion Studies at UMIST," Corrosion 87, San Francisco, CA, Paper Number 368, March 9-13, 1987.

Kobrin, G., "MIC Causes Stainless Steel Tube Failures - Despite High Water Velocity," Materials Performance, pp. 62-63, April, 1994. 
Kobrin, G., "Reflections on Microbiologically Induced Corrosion of Stainless Steels," Biologically Induced Corrosion, NACE-8, (Conference held in Gaithersburg, Md, June 10-12, 1985), 1986.

Kobrin, G., Microbiologically Influenced Corrosion, NACE International, 1993.

Kooij, D., Oranje, J. P. and Hijnen, W. A. M., "Growth of Pseudomonas Aeruginosa in Tap Water in Relation to Utilization of Substrates at Concentrations of a Few Micrograms per Liter," Applied and Environmental Microbiology, pp. 1086-1095, Nov. 1982.

Kustas, F. M., Bates, S. O., Opitz, B. E., Johnson, A. B., Perez, J. M., Farnsworth, R. K., PNL-3513, 1991, Richland, WA.

LeChevallier, J. W., Cawthon, C. D. and Lee R. G., "Mechanisms of Bacterial Survival in Chlorinated Drinking Water," Wat. Sci. Tech., vol. 20, no. 11/12, pp. 145-151, 1988.

Licina, George J., Sourcebook for Microbiologically Influenced Corrosion in Nuclear Power Plants, Electric Power Research Institute (EPRI), 1988.

Little, B. J and Wagner, P. A., "An Electrochemical Evaluation of Microbiologically Induced Corrosion by Two Iron-Oxidizing Bacteria," Corrosion 86, Houston, Texas, Paper Number 122, March 17-21, $198 \dot{6}$.

Little, B. J., Wagner, P. A., McNeil, M. and Mansfield, F., "The Impact of Alloying Elements on Microbiologically Influenced Corrosion,"International Corrosion Congress: Corrosion Control for Low-Cost Reliability Conference, (September 19-24, 1993, Houston, Texas, USA). Paper No. 136, Sponsored by NACE International. Avail: NACE.

Little, B. J. and Wagner, P. A., "An Overview of Microbiologically Influenced Corrosion of Metals and Alloys Used in the Storage of Nuclear Wastes," Can. J. Microbiol., 42: 367-374 (1996).

Lords, R. E., Windes, W. E., Crepeau, J. C., and Sidwell, R. W., "Drying Studies of Simulated DOE Aluminum Plate Fuels," pp. 329-336, INEL-95/00437 Lockheed Martin Idaho Technologies, June 1996.

Louthan, M. R. , Jr., “Microbiologically Induced Corrosion," SRT-MTS-93-0106, July 29, 1993.

Lundberg, L. B., "Corrosion of Spent ATR Fuel Elements Relative to their Dry Storage", ERA-NRE-94-096, EG\&G Idaho, Inc., Aug 1994.

MacLeod, F. A., Guiot, S. R. and Costerton, J. W., "Electron Microscopic Examination of the Extracellular Polymeric Substances in Anaerobic Granular Biofilms," World Journal of Microbiology \& Biotechnology, vol. 11, 481-485, 1995.

McDougall, J., "Microbial Corrosion of Metals," Anti-Corrosion, August, 1966.

Mansfield, F. and Little, B. J., "A Technical review of Electrochemical Techniques Applied to Microbiologically Influenced Corrosion," Corrosion Science, vol. 32, no. 3, pp. 247-272, 1991. 
Mansfield, F., "The polarization Resistance Technique for Measuring Corrosion Currents," Advances in Corrosion Science and Technology, ed. Mars G. Fontana and Roger W. Staehle, vol. 6, 1976.

Miller, J. D. A., "Principles of Microbial Corrosion," Br. Corros. J., 1980, Vol. 15, No. 2.

Nelson, D. Z., Howell, J. P., "Metallography of Pitted Aluminum Clad, Depleted Uranium Fuel," Paper 430, Corrosion 95, 1995.

Newman, R. C., Wong, W. P., and Garner, A., "A Mechanism of Microbial Pitting in Stainless Steel," Corrosion, vol. 42, no. 8, pp. 489-491, 1986.

Okabe, S., Nielsen, P. H. and Characklis, W. G., "Factors Affecting Microbial Sulfate Reduction by Desulfovibrio desulfuricans in Continuous Culture: Limiting Nutrients and sulfide Concentration," Biotechnology and Bioengineering, vol. 40, pp. 725-734, 1992.

Peacock, H. B., Sindelar, R. L., Lam, P. S., "Corrosion of Aluminum Alloys in Simulated Dry Storage Environments", CORROSION 96 NACE Paper No. 134.

Pikul, S. J. and Anderson, D. B., "Field Corrosion Tests for Material Evaluation in Chemical Process Industries," Corrosion 86, (Conference held in Houston, Texas), Paper Number 119, March 17-21, 1986.

Pope, D. H.; "Discussion of Methods for the Detection of Microorganisms Involved in Microbiologically Influenced Corrosion;" Biologically Induced Corrosion, NACE-8; (Conference Held in Gaithersburg, Maryland, June 10-12, 1985); pp. 275-281; ed. S. C. Dexter; 1986.

Pope, D. H., Duquette, D. J., Johannes, A. H., and Wayner, P. C., "Microbiologically Influenced Corrosion of Industrial Alloys," Materials Performance, 1984.

Pope, D. H., "A Study of Microbiologically Influenced Corrosion in Nuclear Power Plants and a Practical Guide for Countermeasures," Electric Power Research Institute (EPRI), EPRI NP-4582, May, 1986.

Pope, D. H. and Zintel, T. P., "Methods for Investigating Underdeposit Microbiologically Influenced Corrosion," Materials Performance, Nov. 1989.

Porter, F. C. and Hadden, S. E., "Corrosion of Aluminum Alloys in Supply Waters," J. Appl. Chem., vol. 3, September, 1953.

Puckorius, P. R. "Controlling Corrosive Microorganisms in Cooling-Water Systems," Chemical Engineering, pp. 171-174, October 23, 1978.

Quigg, C. T., "Dry Storage of Spent Nuclear Fuel," Nuclear, January/February, 1983.

Reed, D. T., Swayabunathan, V., Tani, B. S., and Van Konynenburg, R. A., “Corrosion Product Identification and Relative Rates of Corrosion of Candidate Metals in an Irradiated Air Steam Environment," Mat. Res. Soc. Symp. Proc., Materials Research Society, Vol. 176, 1990. 
Roberge, P. R. and Sastri, V. S., "On-Line Corrosion Monitoring with Electrochemical Impedance Spectroscopy," Corrosion, vol. 50, no. 10, pp. 744-754, October, 1994.

Rosenzweig, W. D. and Pipes, W. O., "Fungi from Potable Water: Interaction with Chlorine and Engineering Effects," Wat. Sci. Tech., Vol. 20, no. 11/12, pp. 153-159, 1988.

Ryskamp, J. M., Adams, J. P., Faw, E. M., Anderson, P. A., "Corrosion Experiments on Stainless Steels Used in Dry Storage, Canisters of Spent Nuclear Fuel Transferred from Wet Storage at the Idaho Chemical Processing Plant (ICPP)" INEL-96/0317, Lockheed Martin Idaho Technologies, Sept 1996.

Sakurai, I., Kosako, Y., Kawamura, Y., Ueki, T., Inoue, Y., and Nakase, T., "Bacterially Associated Corrosion of Aluminum Surface in the Air," Biotechnology Letters, vol. 17, no. 10, pp. 1131-1132, Oct. 1995 .

Sawyer, D. W. and Brown, R. H., "Resistance of Aluminum Alloys to Fresh Waters," Corrosion, vol. 3, pp. 443-456, 1947.

Schmitt, C. R, :Anomalous Microbiological Tuberculation and Aluminum Pitting Corrosion - Case Histories," Biologically Induced Corrosion, NACE -8, (Conference held in Gaithersburg, Md, June 10-12, 1985), ed. S. C. Dexter, 1986.

Sinha, U. P., Wolfram, J. H., Rogers, R. D., "Microbially Influenced Corrosion of Stainless Steels in Nuclear Power Plants", Microbially Influenced Corrosion and Bideterioration, Interantional congress on MIC, Oct 1990, U. of Tennessee, 1990, Editors: Dowling, N.J.

Simpson, P. W. G., "The Effect of Storage in Damp Air and Damp Argon on Pond Water Contaminated CAGR Fuel Cladding Steels," TPRD/B/0860/R86, Job No. : XB180-07.

Smith, T., "The Kinetics of the Corrosion of Low-Hafnium Airconium in Aqueous Sulfuric Acid Solutions," Journal of the Electrochemical Society, vol. 107, no. 2, pp. 82-86, February, 1960.

Starkey, R. L. "Anaerobic Corrosion - Perspectives About Causes;" International Corrosion Conference Series, NACE-8, Biologically Induced Corrosion; (Conference Held in Gaithersburg, Maryland, June 10-12, 1985); ed. S. C. Dexter; 1986, .

Stein, A. A., "Microbiologically Induced Corrosion," Environmental Degradation of Materials in Nuclear Power Systems, The Metallurgical Society, 1988.

Stewart, P. S., Murga, R., Srinivasan, R., and Beer D., "Biofilm Structural Heterogeneity Visualized by Three Microscopic Methods," Wat. Res., vol. 29, no. 8, pp. 2006-2009, 1995.

Stoecker, J. G., "Guide for the Investigation of Microbiologically Induced Corrosion," Materials Performance, 1984.

Suleiman, M. I., Ragault, I., and Newman, R. C., "The Pitting of Stainless Steel Under a Rust Membrane at Very Low Potentials," Corrosion Science, Vol. 36, No. 3, pp 479-486, 1994. 
Tatnall, R. E., "Case Histories: Bacteria Induced Corrosion,” Materials Performance, pp. 41-48, August, 1981.

Tiller, A. K. and Booth, G. H., "Anaerobic Corrosion of Aluminum by Sulphate-Reducing Bacteria," Corrosion Science, vol. 8, pp. 549-555, 1968.

Tiller, A. K., Metallic Corrosion and Microbes, National Corrosion Service, National Physical Laboratory.

Tiller, A. K., "Is Stainless Steel Susceptible to Microbial Corrosion?" National Corrosion Service, March $8-10,1983$.

Videla, H. A., "The Action of Cladosporium resinae Growth on the electrochemical Behavior of Aluminum," Biologically Induced Corrosion, NACE-8, (Conference held in Gaithersburg, Md, June 10-12, 1985), ed. S. C. Dexter, 1986.

Vitikainen, E. A., "IAEA/BEFAST II: Research on Spent Fuel Behavior in Extended Storage," Nuclear Europe Worldscan, Vol. 10 \#(3-4) 36, 1990.

Wagner, P. A. and Little, B. J., “Application of a Technique for the Investigation of Microbially Induced Corrosion, Corrosion 86, (Conference Held in Houston, Texas), Paper Number 121, March 17-21, 1986.

Wagner, P. A. and Little B. J., "Impact of Alloying on Microbiologically Influenced Corrosion-A Review," Materials Performance, pp. 65-68, September, 1993.

Walch, M. and Mitchell, R, "Role of Microorganisms in Hydrogen Embrittlement of Metals," Corrosion/83, NACE International, Houston, TX, Paper No. 249, 1983.

Wende, E., Characklis, W. G., Grochowski, J., "Bacterial Growth in Water Distribution Systems," Wat. Sci. Tech., vol. 20, no. 11/12, pp. 521-524, 1988.

Wright, T. E. and Godard, H. P., "Laboratory Studies on the Pitting of Aluminum in Aggressive Waters," Corrosion, vol. 20, pp. 195-198 June 1954.

Yau, T. L., "The Performance of Zirconium Alloys in Sulfide Solutions," Corrosion, vol. 38, no. 12, pp. 615-620, Dec., 1982

Yau, T. L. and Webster, R. T., "Corrosion of Zirconium and Hafnium," Metals Handbook, 9" ed., Metals Park, Ohio, pp. 707-721, 1978. 
Appendix A

\section{MIC Techniques and Methodology}




\section{Appendix A}

\section{MIC Techniques and Methodology}

Acceptance of MIC is relatively recent. As a result, investigation methods are being developed rapidly. Currently, there are several methods employed to identify the occurrence of MIC. In practice, MIC is identified as a causative corrosion mechanism only after no alternative mechanisms can reasonably explain the observed corrosion and after several methods have indicated the possibility of MIC. Investigation methods include site examination, microbiological analysis, metallurgical analysis, chemical analysis, and electrochemical analysis.

\section{Site Examination}

Site examination is completed with sight, smell, and/or touch. For example, nodules of rust, brown or black, suggest that MIC is present. Other identifying signs of MIC include hydrogen sulfide odor, discolored or foul-smelling water, slime-covered surfaces, and the characteristic shapes of deposits or penetrations. Also, the local conditions also must be favorable for MIC to occur such as stagnant or low water flow, intermittent operation, water availability, lay-up methods, and operating time.

The site should be examined with respect to available nutrients. Even trace nutrients may be sufficient to maintain a bacterial colony as nutrients may be adsorbed and accumulated by a biofilm to concentrations sufficient for microbial growth. Therefore, the measurement of nutrient concentration in the bulk water may not be representative of the entire system under study.

All common alloys such as iron, steel, 304 SS, copper, copper-nickel, Monels, and admiralty brass have all been documented to be attacked by MIC. The only apparent MIC-resistant metals are titanium and nickelchrome alloys. Preliminary information also indicates that zirconium is resistant to MIC. If any or all of the above examinations have been completed and MIC appears possible, additional testing should be initiated to either prove or discount the occurrence of MIC.

\section{Sampling}

A MIC investigation requires collection of water samples, microbiological samples, and solid samples of corroded areas (including corrosion products). In general water, microbial, and solid samples must be kept in separate containers. Water samples should be taken from the water inlet and immediately upstream and downstream of the component(s) of interest. Microbiological samples should be collected using flow-through methods as grab samples can be unreliable. Solid samples should be collected with a sterile spatula and placed in a sterile container with a tight-fitting lid.

Water and microbiological samples should be subjected to chemical and biological analyses. Solid samples should be subjected to typical metallurgical examinations. Initially, under-deposit areas of a metal surface should be examined visually and characterized. Corrosion deposits should be removed carefully to avoid physical damage and to avoid chemical or biological contamination. The methods for analysis of each sample type is described below. 


\section{Microbiological Analysis Methods}

Both water and metal samples may be examined using microbiological methods such as culture methods, detection of biochemical factors or metabolic products, and various forms of microscopy. The purpose of these methods is to identify the presence of microbes that are known to cause MIC (e.g., sulfur reducing or iron bacteria).

Culture methods involve collecting, growing, and analyzing a microbiological sample. Plate counts obtained from culture methods may be used to quantify the number of bacteria present. The number of bacteria present in a sample is estimated from the number of colonies counted on a plate after a specified period of growth time. The number of colonies counted is compared to a known sample. Some species of MIC-causing bacteria such as Gallionella and sulfur-reducing bacteria are not amenable to this technique. A related method involves growing samples on selective media, then counting the resulting colonies. The problems with these methods are that they take a long time (up to weeks) and some species of bacteria are not easily identified. A related method involves placing microbes on a plate containing INT dye. If microbes are present, the dye will change colors in a couple of hours.

Another method involves detection of unique chemical compounds. Microbes produce specific biochemical factors and metabolic products. Detection of these factors or metabolic products using GC/mass spectrometry, fourier transformed IR spectroscopy, lipid chemistry separation, and transformation techniques may help to verify the presence of specific microbes. The drawback to this type of method is that the analytical chemistry equipment required is expensive, and reliable results may not be available for weeks. Also, detection of metabolic products such as hydrogen sulfide, alcohols, organic acids, and sulfuric acid may be misleading as more than one type of bacteria produce each of these compounds.

Preparation of solid samples for scanning electron microscopy (SEM) or optical microscopy must be accomplished carefully to avoid destruction of bacteria and biofilm. Typical metallurgical sample preparation involves etching with strong acids, abrasion and polishing, and extreme temperatures (samples are often collected using torches). As a result of the preparation methods, microbial colonies are not seen on SEM photographs. Proper microbiological preparation includes fixation in gluteraldehyde, rinses in increasing ethanol/water solutions, and an acetone rinse. Detailed sample preparation methods may be found in the literature.

Microscopy is another common microbiological method used to identify the type of bacteria present in a solid sample. For example, Immunofluorescent reagents (fluorescent antibodies) may be added to a sample prior to inspection under a microscope. The reagents added react only with tissues associated with a specific bacteria and will cause the bacteria of interest to glow. This method is referred to as immunofluorescent microscopy.

Epifluorescence microscopy involves reacting an epifluorescent reagent such as fluorescein isothiocyanate, acridine organe, or any other protein-staining or nucleic acid-staining dye to the sample before inspection with a microscope. A skilled microbiologist is then able to distinguish between various strains of bacteria. 
The immunochemical/enzyme-linked method is available in a simplified kit. Inexperienced personnel are able to use this kit to identify the specific bacteria present in a sample in approximately 1 hour. The kit contains a cellulose nitrate, a buffered washing solution, and various antibodies and enzymes. To identify the species of bacteria present, a sample is collected on the cellulose nitrate, rinsed in the buffered solution, and reacted with various antibodies and enzymes. The color of the resulting solution is compared with controls consisting of known samples of bacteria (similar to $\mathrm{pH}$ paper).

\section{Metallurgical Methods}

These methods include low- and high-power optical microscopy and scanning electron microscopy. Low- and high-power optical microscopy will serve to better characterize the appearance of the corrosion site and to identify the nature of corrosion. MIC may be suspected if pitting corrosion is found under discrete deposits. The nature of the attack should be well characterized by microscopy (i.e., pitting, intergranular attack, or the preferential attack of one phase.) Information also may be obtained by examination of a crosssection of the affected area with a scanning electron microscope (SEM) to provide additional details concerning the nature of the attack. As discussed previously, unless solid samples are prepared carefully, no biofilm or microbes will be seen on samples prepared with typical methods. Strict adherence to biological sample preparation methods are required to detect biofilms with microscopy.

\section{Chemical Methods}

Confirmation of MIC usually requires that the deposits accompanying the corrosion products be analyzed. This should include an elemental analysis and a determination of the organic/inorganic carbon ratio. For example, high levels of iron, manganese, and chlorides usually indicate Gallionella. High sulfur indicates the presence of sulfur oxidizers or sulfate reducers. High iron could indicate iron bacteria. Also, organic carbon content in excess of $20 \%$ suggests the presence of microbes. Also, manganese and chloride found with high iron (especially non-ferrous metals) would imply the presence of iron oxidizers such as Gallionella or Siderocapsa.

$\mathrm{X}$-ray diffraction analyses for compounds tend to be misleading because many key corrosion products will be amorphous and thus will not be identified. In addition to elemental analysis, loss on ignition of the deposit will determine the percent organic matter. Dried bacteria deposits typically show $30 \%$ or more mass loss on ignition. Positive results obtained by the above-mentioned methods provide good evidence for the occurrence of MIC.

\section{Electrochemical Methods}

The MIC mechanisms are complex, and some electrochemical techniques may be misleading unless used and interpreted carefully (Dexter, 1991). Many electrochemical methods such as measurement of the corrosion potential, polarization resistance, solution potential, electrical impedance spectroscopy, and the dual cell method have been identified in the literature. These methods are used to estimate the corrosion rate and may provide valuable insights into corrosion mechanisms. ${ }^{c}$

c. See References for a complete discussion of electrochemical methods. 
The corrosion potential, $\mathrm{E}_{\text {corr }}$, may be used to predict MIC if the mechanism is known. However, these data are misleading if the mechanisms are not known. Measurement of $E_{c o r}$ is accomplished with a stable reference electrode, a high impedance voltmeter, and a recording device. The polarization resistance $\mathrm{R}_{\mathrm{p}}$ should be measured at the same time as $\mathrm{E}_{\text {cor }}$ to identify an increase or decrease in the corrosion rate over time (these changes are indicative of MIC). 
Appendix B

Tasks to be Done at the INEL 


\section{Appendix B}

\section{Tasks to Be Done at the INEL}

\section{Approach:}

This effort will include the following majors tasks.

1. Assess the microbial component in Basin 666 at the INEL.

2. Develop and improve protocols for water quality in terms of microbial presence.

3. Evaluate the role of MIC in fuel deterioration and the life cycle of fuel cans.

4. Evaluate the role of identified microbial activity and biofilms on the drying process.

5. Assess the dry storage issue based on an evaluation of the role of microbial activity continuing in fuel channels during dry storage.

Tasks:

1. Assess the microbial component in Basin 666 at the INEL.

1.1 Develop sampling procedures and protocols to determine the microbial ecology of the SNF. This task would use personnel from operations and AEDL to evaluate the constraints and costs of sampling procedures. Samples of basin water and organisms should be obtained and cultured.

1.2 Determine the types of organisms present in the bulk water stage.

1.3 Determine the biofilm formation rate on coupons placed in the basins.

1.4 Determine the organisms that are present in the biofilms. Lab-scale corrosion tests should be conducted after growing biofilms and compared with current attack by resident water samples.

2. Develop and improve protocols for water quality in terms of microbial presence.

Biofilms and algae increase the cost of fuel storage due to poor visibility and increased contamination due to concentration effects. This means more time to get the job done, greater waste generation, and exposure to personnel.

2.1 Define what is acceptable water quality in terms of basin operations, worker protection, fuel protection, and the ability to transfer the fuel. This would include working with the operations staff, developing housekeeping rules, and evaluating biocides. 
2.2 Develop a methodology for reducing the microbial presence once it is identified from the bulk water, and develop ways to remove biofilms. Air flow, surface skimming, makeup water treatment, microbial scavenging absorbents, cleaning items before they enter storage, and reducing the amount of nutrients are all options that are not presently dealt with.

2.3 Evaluate the constraints of corroded fuel on the transition to dry storage.

2.4 Establish a routine monitoring program for Building 666 that tracks the microbial content in the bulk water and biofilm formation.

2.5 Evaluate the efficiency of some biocides, and the ability to remove biofilms. Evaluate the corrosion effect of any biocide on materials coupled in fuel storage basins to ensure that the cure is no worse that the cause.

3. Evaluate the role of MIC in fuel deterioration and the life cycle of fuel cans.

3.1 Develop a test plan for establishing and measuring the presence of biofilms.

3.2 Clarify the role of biofilms in localized corrosion by conducting accelerated and long-term . testing of coupons in pool water in the presence of microbes. Biofilm studies will be done that allow staining of microbial colonies and subsequent subsurface attack mapping. What is required is to directly connect microorganisms to a pitting attack versus general attack by high-purity water.

3.3 Evaluate the role of MIC effects on the corrosion rate compared to other mechanisms such as electrochemical corrosion.

3.4 Evaluate the synergistic effects of MIC, crevice corrosion, intergranular attack, and other mechanisms. Determine whether biofilms up take Al or transfer it to the basin water. A microdetermination is needed of the active corrosion species in the pits.

3.5 Determine a cost estimate of putting fuel into dry storage that has been damaged during wet storage. Compare this cost estimate with the cost of mitigating and monitoring microbial activity.

3.6 Develop mitigation techniques for controlling any organisms that could be introduced to the basins if they are identified as a potential hazard.

4. Evaluate the role of identified microbial activity and biofilms on the drying process.

4.1 Identify biofilm and microbial response to the drying process.

4.2 Evaluate whether initiated pits will continue to grow after the drying process.

4.3 Evaluate whether drying will affect biofilm within fuel channels. 
5. Assess the dry storage issue based on an evaluation of the role of microbial activity continuing in fuel channels during dry storage.

5.1 Sample and evaluate dry storage fuel at LANL.

5.2 Perform tests under simulated conditions for INEL dry storage.

5.3 Correlate the test data from INEL with the field data from LANL. 
Appendix C

Trip Reports 


\section{Appendix C}

\section{Trip Reports}

Date: July 26, 1996

To: R. P. Lengyel

MS 3920

6-9683

From: $\quad$ R. E. Mizia

MS 3114

6-3352

J. H. Wolfram

MS 2203

6-1809

Subject: $\quad$ TRIP REPORT, MICROBIOLOGICALLY INFLUENCED CORROSION SURVEY OF SRS. AND ORNL - REM-06-96 AND JHW-07-96

Savannah River Site Visit

SRS Personnel:

Roseanne Benson

Engineer, Bäsin Engineering

Steve Burke Manager, Basin Engineering

Tami Capelleti

Manager, Materials Technology Section

Rich Dieble Engineer, Basin Engineering

James Howell Advisory Engineer, Materials Application \& Corrosion Technology

Natraj Iyer . Manager, Materials Application \& Corrosion Engineering

Mac Louthan Senior Advisory Engineer, Materials Application \& Corrosion Engineering John Mickalonis

The trip to visit to SRS was to confer with staff about the contribution of microbial influenced corrosion (MIC) to the deterioration of materials, such as used for nuclear fuel cladding and the component and structures for the storage pool. Two interesting points were produced during this visit. It was found that the corrosion test program using SRS basin water is showing corrosion pit initiation on the Al samples. This result had not been observed before our visit. This test program is being continued to further evaluate this finding. The second thing we observed was that corrosion product was visible on structures when we visited the L Basin fuel storage pool.

The initial meeting with SRS personnel included general discussions on possible contribution of MIC to spent nuclear fuel deterioration in pool storage. SRS became interested in the subject through interactions with the INEL and the Montana State University Center for Biofilm Engineering on degradation mechanisms of 
Al-clad fuel. The subject of MIC of foreign research reactor fuels being shipped to SRS for storage has recently come up. In light of this, SRS is presently undertaking the following proactive steps in the microbial area:

1. Spent Nuclear Fuel (SNF) storage pool water sampling program.

2. Clean-up program for SNF fuel pool algae growth (bath tub ring).

3. SRS is dimming SNF fuel storage pool lighting when work is not being performed.

4. Conduct a laboratory testing program to determine the potential role of MIC in the storage of SNF fuel and quantify the susceptibility of SNF materials to MIC. (This test program is described below.)

Mac Louthan made a presentation entitled "Potential for Microbiologically Influenced Corrosion in the Savannah River Spent Fuel Storage Pools" (Attachment 1) which had been presented at the recent (May 1996) NATO Advanced Research Workshop (ARW) on the effect of biological mediated processes on interim storage of spent fuel. The conclusions of this talk were:

- Probability of MIC is low

- The consequences of MIC can be handled by engineering controls

- Periodic monitoring is warranted.

The interesting thing is that after discussions of our program, we were able to agree on a proposed test program and rationale for the MIC investigation (Attachment 2). The critical points of agreement between SRS and us is that pitting is present that cannot be explained by abiotic mechanisms and there is an incomplete historical data base on MIC in SNF storage.

The evaluation approach of SRS for assessing the potential contribution of MIC to fuel pool corrosion is to follow the work which we started through the Montana State University Biofilm Center. Their study centers in determining if basin water of high purity and low conductivity (Receiving Basin for Offsite Fuel Pool water, 0.6 to 1.2 microsiemens $/ \mathrm{cm}$. or less), is capable of causing localized corrosion in the form of pits or crevices in the AI SNF cladding. Their first attempt in setting up the corrosion cells (INEL modified design) for long term coupled biotic- abiotic studies, produced the following results:

- $\quad$ SRS was not able to keep the abiotic cells sterile for the initial study. The test was completed after three months and the coupons were removed. However, a thorough inspection had not been performed. John Mickalonis and Jim Wolfram looked at a few of the coupons under a 10x stereoscope. On several of the coupons, pit initiation could be detected. The pits had no associated surface corrosion product. This observation is similar to what we have seen in the basin at Building 666 .

- The observation that pits are formed in the SRS studies using so-called non-corrosive water correlates well with the INEL studies. This preliminary finding of pit initiation could have been influenced by the presence of microorganisms. This finding does indicate that pitting can be initiated on $\mathrm{Al}$ alloy in low chloride and low-conductivity water. 
A visit to the SRS L Reactor Basin verified that corrosion had occurred or was occurring. This fuel storage basin is attached to the $L$ Reactor which was constructed in the early 1950s. It was shut down in 1968 and was restarted in 1985 with a refurbished fuel pool. Plant service water with an approximate conductivity of $80 \mu \mathrm{S} / \mathrm{cm}$ was used for the initial basin filling. An algae growth on the water system sand filters was initially controlled with additions of sodium hypochlorite which caused the water conductivity to degrade to about $150 \mu \mathrm{S} / \mathrm{cm}$. A water cleanup program was instituted in July 1995 and the conductivity has been reduced to about $1.5 \mu \mathrm{S} / \mathrm{cm}$. Although the fuel cladding surfaces could not be directly observed, whitish tubercule corrosion product could be seen on various submerged surfaces of fuel storage racks and other structural members.

The questions that arise from the $\mathrm{L}$ basin visit are as follows:

1. Will an improvement in fuel storage basin water quality mitigate earlier abiotic and biotic corrosion mechanisms?

2. What is the correlation in corrosion performance between basin Al structural components (which are showing damage in the $\mathrm{L}$ basin environment) and SNF Al cladding?

3. The pitting observed in the corrosion tests presently being run at SRS show no corrosion product. There is a corrosion product visible on the $\mathrm{L}$ basin structural components. [What explains these differences....?]

Qak Ridge National Laboratory Visit

ORNL Personnel:

$\begin{array}{ll}\text { Robert Childs } & \text { Facility Manager, BSR, Research Reactors Division } \\ \text { David Cook } & \text { Manager, Nuclear Analysis, Research Reactors Division } \\ \text { J. E. Goss } & \text { Project Manager, Engineering \& Safety Analysis (H\&R Technical Associates) } \\ \text { Rodney Knight } & \text { Research Reactor Fuel Element Coordinator, Research Reactors Division } \\ \text { Daniel Pinkston } & \text { Nuclear Design Engineer, HFIR, Research Reactors Division } \\ \text { Richard Rothrock } & \text { Nuclear Engineer, Research Reactors Division }\end{array}$

This visit to Oak Ridge provided us a chance to meet several basin operations personnel and the lead engineer who was involved with the initial fuel fabrication of Al-clad research reactor fuel (Rod Knight). We each gave a short presentation on the MIC investigation for the national spent fuel program and the mechanisms of MIC. We were given a presentation on and a tour of the High Flux Isotope Reactor (HFIR). We then toured the Bulk Shielding Reactor (BSR) fuel pool. We finished the visit with a presentation by J. Goss on underground storage of fuel.

The HFIR is a 85-MW production and research reactor that provides a high, steady-state neutron flux for irradiation experiments and transuranium isotope production. The nuclear fuel is a $U_{3} \mathrm{O}_{8}-\mathrm{Al}$ cermet that is clad with $\mathrm{Al}$ alloy 6061 . Due to the fact that the reactor was being prepared for start-up, we were unable to directly observe the fuel. We used the HFIR basin video camera system to make our observations. The pool 
structural components and the tops of the stored fuel appeared very clean. Contributing conditions for this status are the following.

- The reactor is in the same basin as the fuel storage. This leads to high neutron fluxes from the reactor and the decaying fuel elements which could act as a sterilization system for the pool components and the stored fuel.

- The air handling system in the reactor pool area basin is similar to a laminar air hood system used to transfer microbial cultures aspectically. This air flow system removed airborne particles before they contact the water's surface and sweeps them through several filters before recycling back to the basin area.

The HFIR engineering staff (Dan Pinkston) is presently in the process of designing and building corrosion coupon racks to be placed in the HFIR pool (Attachment 3).

The BSR Facility has been shutdown and the fuel and pool are under the jurisdiction of EM-30. The BSR fuel storage basin showed evidence of corrosion that was not apparent at the HFIR Facility. In discussing the conditions of the basin with its manager (Robert Childs), we learned that the water quality is always maintained at a low conductivity of less than $50 \mu \mathrm{S}$. Observations, however, showed numerous areas of . corrosion product on submerged fuel handling tools and other $\mathrm{Al}$ structural components. This fact also indicates that $\mathrm{Al}$ can corrode in low conductivity waters. Other indications of microbial activity included green biomass as well as wall and floor sludge.

\section{Conclusions:}

- There has never been consideration given to MIC when previous corrosion investigations were conducted.

- A microbial assessment program (sampling and analysis) should be developed to gather more information on fuel storage pool conditions

- Abiotic conditions and processes cannot explain or account for all of the deterioration of metals in fuel storage basins

- A testing program should be designed and implemented to determine the pit initiation mechanisms for Al-clad SNF and Al structural components in high purity fuel storage basin water

cut

Attachments

cc: L. J. Johnson, MS 2203

R. E. Mizia File

J. H. Wolfram File 
Date: $\quad$ August 7, 1996

To: $\quad$ File

From: $\quad$ R. E. Mizia

MS 3114

$6-3352$

J. H. Wolfram

MS 2203

$6-1809$

Subject: TRIP REPORT - MICROBIOLOGICALLY INFLUENCED CORROSION SURVEY OF HANFORD SITE - REM-07-96 and JAW-08-96

Reference: A. B. Johnson, Jr. and S. P. Burke, K Basin Corrosion Program Report. WHC-EP-0877, dated September, 1995

The visit to the Hanford site started with a meeting with A. Burt Johnson of the Pacific Northwest National . Laboratory on July 18,1996 . He has participated in and chaired various national and international technical sessions on nuclear fuel storage and degradation mechanisms of nuclear fuel and storage structures. We discussed the Hanford corrosion data contained in a report that he co-authored (Reference). The conclusions reached in Section 9 show that corrosion is a serious issue for the $K$ East Basin and has a minimal impact in the $\mathrm{K}$ West Basin. The pitting of $\mathrm{Al}$ fuel canisters in the $\mathrm{K}$ East Basin is mentioned, but there is no discussion of any possible microbial component.

We also met that afternoon with Bruce Makenas (Fellow Engineer, Space and Defense Power Engineering Development) of Westinghouse Hanford Company. Bruce described his work on characterization of the $\mathrm{K}$ East Basin fuel and dirt and/or sludges found on the fuel surface and the basin floor. The fuel cladding suffered damage when it was removed from the reactor and these cladding breaks allowed the uranium fuel to be corroded. Bruce showed inspection videos where the sludge depth was measured to a depth of 31 inches. The fuel surface was shown to have a fine dirt or dust clinging to it. Analyses of the sludge indicated that high levels of total organic carbon (TOC) are present.

We visited the $\mathrm{K}$ Reactor area on Friday, July 19. We had a kickoff meeting with the following operations and engineering staff:

Dave Bergmann, Engineer, K Basins Projects

James Jernberg, K Basins Projects

Ray Larson, Operations Representative, K Basins Operations

They discussed the fuel storage history and the plans for movement of the fuel from both $\mathrm{K}$ East and $\mathrm{K}$ West Basins to a dry storage facility. The plan calls for construction of a dry storage facility that will dry the fuel and store it in modules. The schedule calls for the first fuel movement to this facility in December 1997. The 
first fuel will be moved from the $\mathrm{K}$ East Basin due to the better condition of the fuel. It is anticipated that the damaged fuel from the K West Basin will start shipping in early 1998.

We were given a tour of the $\mathrm{K}$ West Basin due to the cleanliness of this facility as compared to the $\mathrm{K}$ East Basin. We were able to make this tour in our street clothes. The $\mathrm{K}$ East Basin would have required anti-c clothing and exposure to ourselves and the Hanford staff. They estimate that $40 \%$ of the fuel in the East Basin is damaged by corrosion. The high radiation levels indicate severe and constant dissolution of the fuel into the basin water. The fuel storage canisters were easily visible and showed no apparent damage from our visual inspection. However, all the fuel assembles in this pool are in cans with lids. No visual inspection of the fuel was possible. The water quality typically runs less than $100 \mu \mathrm{S} / \mathrm{cm}$. There was no gross visual evidence of microbiological or algae growth.

We finished our tour with a meeting with Dean Siddoway who is the K Basins Area Director. Dean stated that Hanford has an aggressive schedule for fuel movement to the dry storage facility that they intend to meet.

cmt

cc: L. J. Johnson, MS 2203 


\section{Appendix D}

\section{Biocide Addition Corrosion Test Plans}




\section{Appendix D}

\section{Biocide Addition Corrosion Test Plans}

Biofilms may contribute to accelerated AI and 304 SS corrosion rates within spent nuclear fuel storage pools. It is important to measure these microbial assisted rates and develop methods to control the biofilm. Biofilm control methods must utilize biocides that do not cause additional corrosion of the SNF or fuel storage components.

The MIC biocide study will evaluate the effect of biocides (ozone and hydrogen peroxide) upon corrosion of Type $6061 \mathrm{Al}$ and Type 304 SS under biotic and abiotic conditions. The test plan is as follows:

1. All glassware and fittings exposed to test solution will be autoclaved at 15 psi steam pressure for 1 hour.

2. Untreated corrosion coupons will be measured, cleaned, dried, and weighed. Just prior to placing the coupons in the test cell they will be dipped in ethyl alcohol and air dried. This is to sterilize the surface prior to testing.

3. Treated coupons will be autoclaved for 8 hours at $105^{\circ} \mathrm{C}$. This will form a layer of boehamite on the surface of the coupon. This is similar to that found on irradiated fuel elements, but will not be as thick due to the shorter formation time. This thicker oxide layer is thought to be more protective than the lower temperature oxide formed at room temperature on the $6061 \mathrm{Al}$. The coupons will be air dried, weighed, and measured for dimensions. Just prior to placing the coupons in the test cell, they will be dipped in ethyl alcohol and air dried. This is to sterilize the surface prior to testing.

4. Approximately 2,300 mL of CPP-666 basin makeup water will be added to the cell. This makeup water contains the same organisms found in the CPP-666 basin.

5. Every 30 days, approximately $500 \mathrm{~mL}$ of water will be removed from each cell, and $500 \mathrm{~mL}$ of filtered, autoclaved makeup water will be added to the cell. The solution will be added through the stop cock using a tubing pump to add the water. The water addition is to provide actual nutrients to the cell for continued microbial growth. Nutrients will be added if biofilm does not form within 60 days. This will allow growth to occur to allow information to be derived on the biocide kill rate. If nutrients are added, no additional makeup water will be used.

6. $E_{\text {corr }}$ and the corrosion current will be monitored initially and then every 2 days until the end of testing.

7. The first coupon will be pulled from each test cell after 2 months if a visible biofilm formation is observed. The coupons will be stained for living cells and counted. 
8. Once it has been determined that a biofilm has been formed, testing with biocides will start.

(a) Ozone will be introduced at concentrations of $0.05 \mathrm{ppm}$ and $0.1 \mathrm{ppm}$ for 30 minutes. The ozone concentration in solution will be measured at 30 minutes and 1 hour to measure fall off.

(b) The same time frame will be followed by hydrogen peroxide at $20 \mathrm{ppm}$ and $500 \mathrm{ppm}$.

(c) If required, concentrations of the biocide will be measured beyond 1 hour to determine residence time prior to $95 \%$ consumption and/or the method limit.

9. One coupon from each cell will be pulled and stained for live organisms, and the cells will be counted to determine kill rate.

10. One coupon will be pulled from each cell 1 month after the biocide exposure to determine any residual biotic growth. If substantial biotic growth is observed, the test will be terminated at this point and current biocide concentrations will be re-evaluated.

11. The last coupons will be pulled from each cell after 2.5 months after biofilm formation to determine any residual biotic growth or will be used for a second biocide exposure period.

12. All coupons will be cleaned, weighed, and measured using image analysis to determine effects of biocide additions on the corrosion of the $6061 \mathrm{Al}$. The corrosion rates and types of attack will be compared to the base line corrosion coupons being tested in the CPP- 666 basin. 
Appendix E

Photographs 


\section{Appendix E}

\section{Photographs}

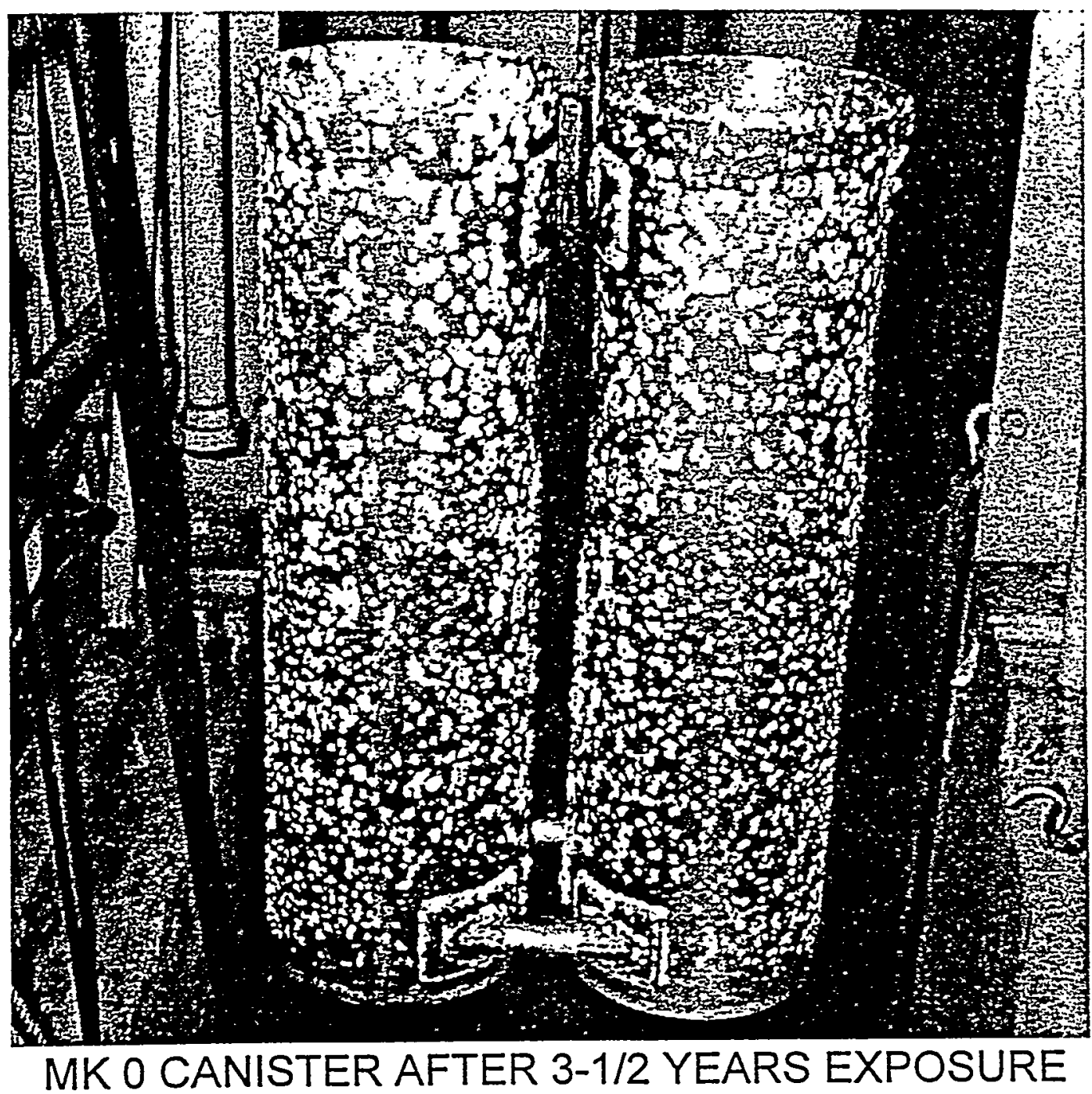

Figure E-1. Corrosion of Al alloy fuel cladding (Johnson 1995).

The following photographs are reproduced in this report by permission of NACE. These photographs were taken from "Microbially Influenced Corrosion" by G. Kobrin, NACE International, 1993. 


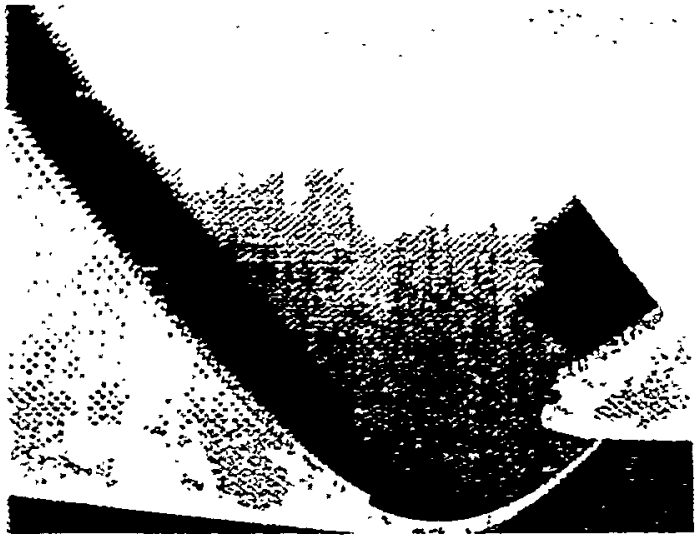

FIGURE 4.9

View of a SS couch roll shell failure due to metallurgical stress caused by MIC. The bacteria were growing on the inner surfaces of the suction holes. (Figure 4.10)
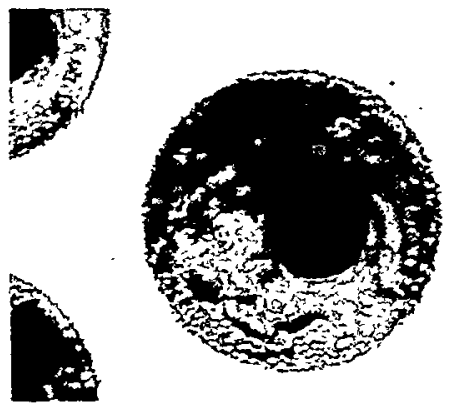

FIGURE 4.10

Close-up view of the biomass deposited on the inner suriaces of the suction holes on a SS couch roll shell. (Figure 4.9)

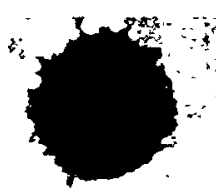

4 .
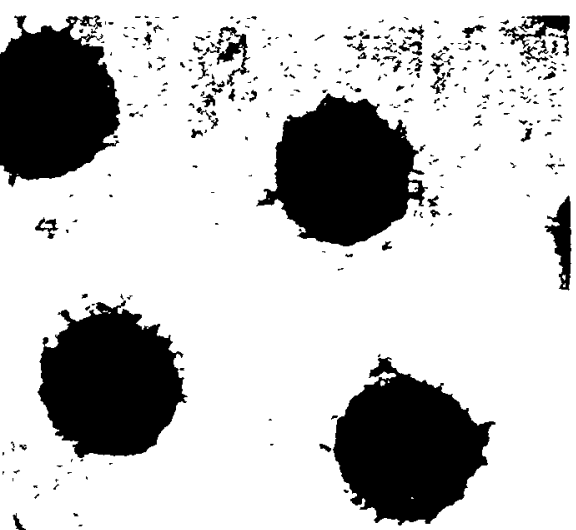

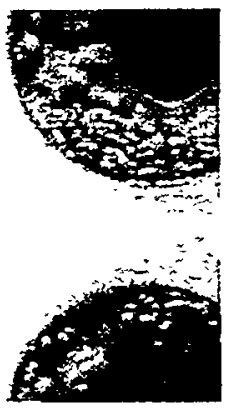




\title{
Catalog of Color Photographs of MIC
}

\author{
Compiled by $\mathrm{G}$. Kobrin
}

This section contains color photographs of conditions-typical biofilm and biomound deposits and corrosion morphologies-that relate to observed cases of MIC. Also included are a series of photomicrographs of algae, fungi, and bacteria known to be associated with MIC.

Most of these photos have not appeared in the technical literature but are from the personal files of the following:

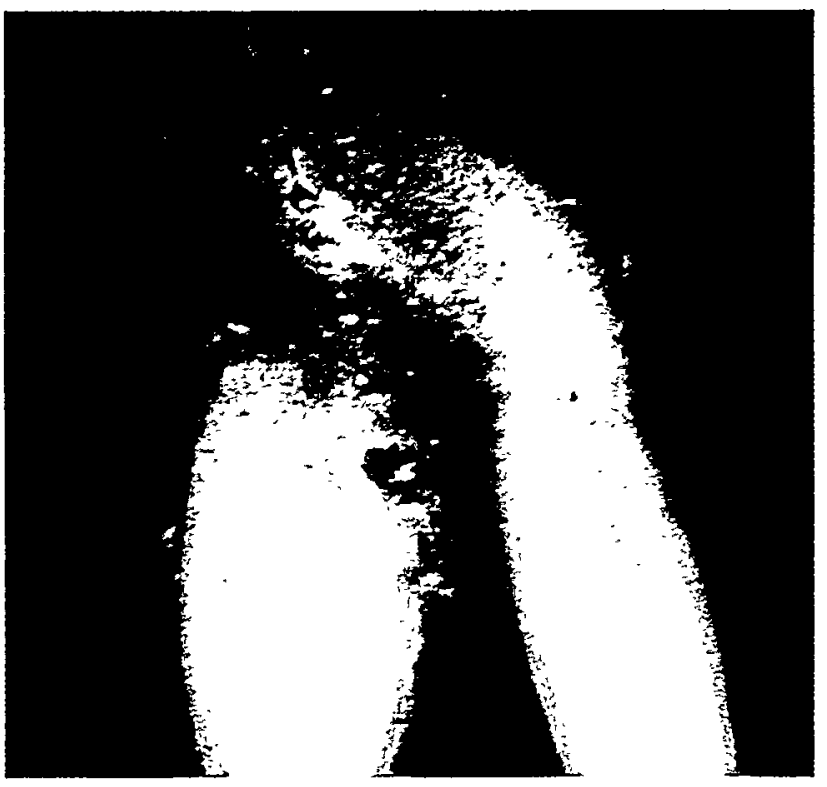

FIGURE 9.1

Biomound deposits along weld seam in bottom of 304 (UNS 530400) stainless steel (SS) tank after several months' exposure to stagnant, ambient temperature well water used for hydrostatic testing and ballast. Deposits were rich in iron- and manganese-utilizing bacteria (Gallionella, Siderocapsa), and iron and manganese compounds, predominantly chlorides.'
1. G. Kobrin

2. R.E. Tatnall

3. S.W. Borenstein

4. R.W.Lutey

They are referenced by the above numbers following each photo caption.

This section is included in the manual to help the reader identify and analyze potential MIC problems. Many additional color photographs, most taken from the literature, appear in the Case Histories section.

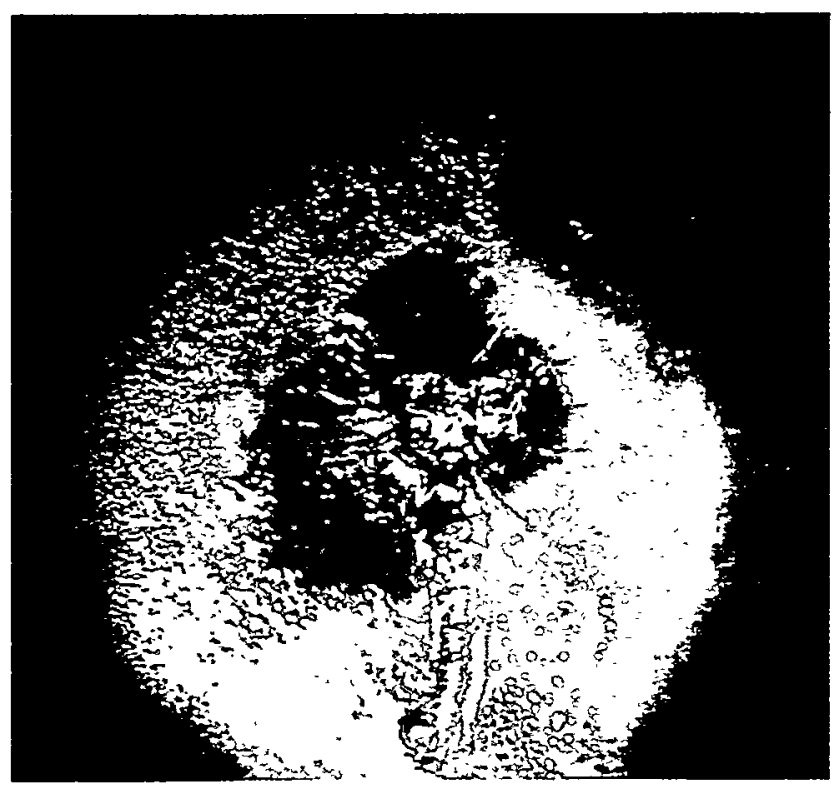

FIGURE 9.2

Closeup of Figure 9.1. Approximate size of deposit is 8 $\times 10 \mathrm{~cm}(3 \times 4$ in.).' 


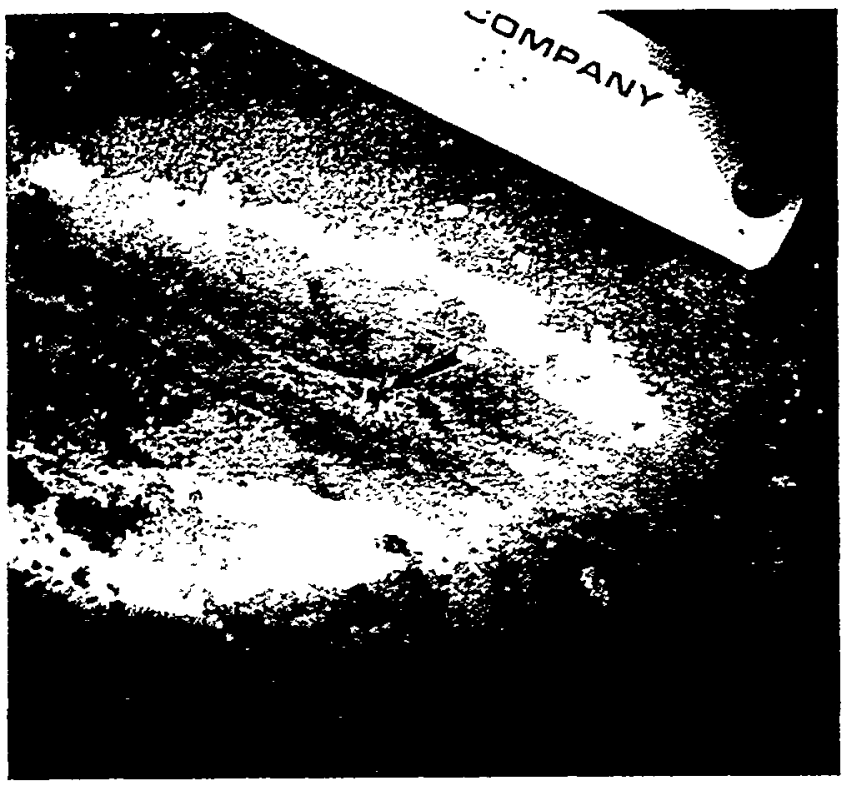

FIGURE 9.3

Pit (arrow) at edge of weld after removal of deposit shown in Figure 9.2 and probing area with an ice pick.'

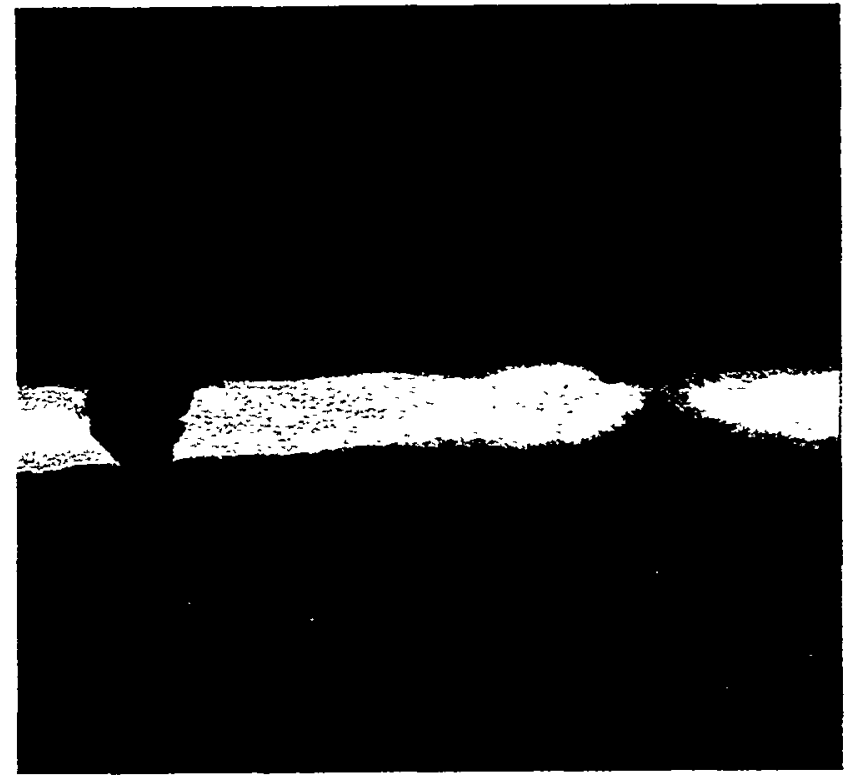

FIGURE 9.4

Radiograph of weld seam shown in Figure 9.3. Note attack is confined primarily to weld metal. ${ }^{1}$

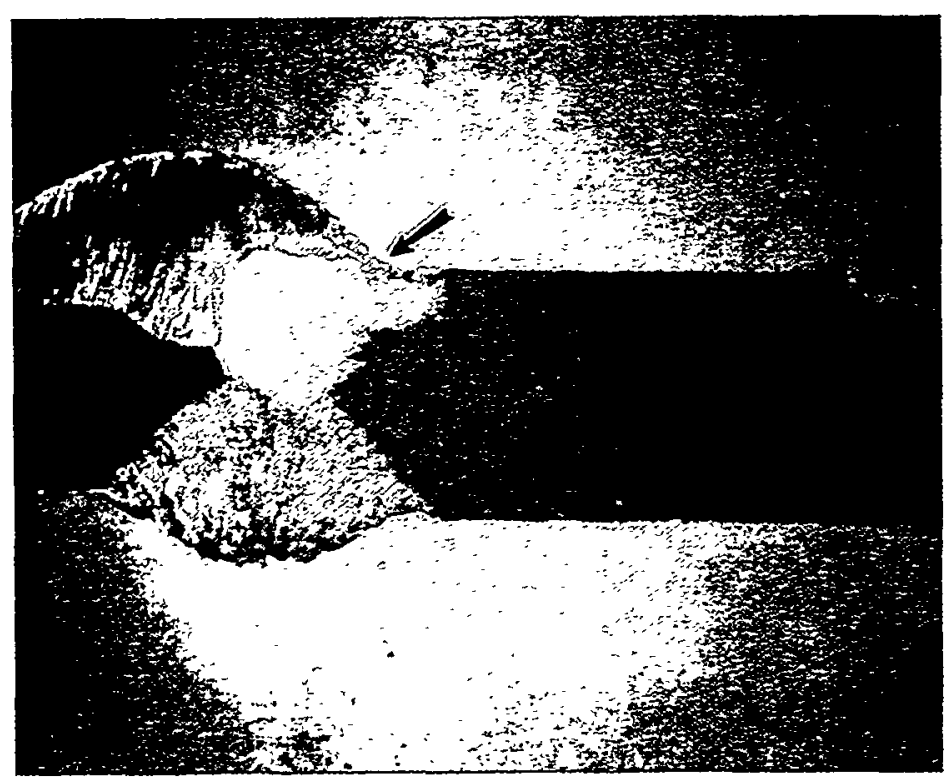

FIGURE 9.5

Cross-section through a pit in a weld seam under one of the biomound deposits shown in Figure 9.1. Note the minute opening (arrow) on the surface as the entrance to a large roundish subsurface cavity beneath a thin shell of metal, lypical of MIC at 300 series SS welds.'

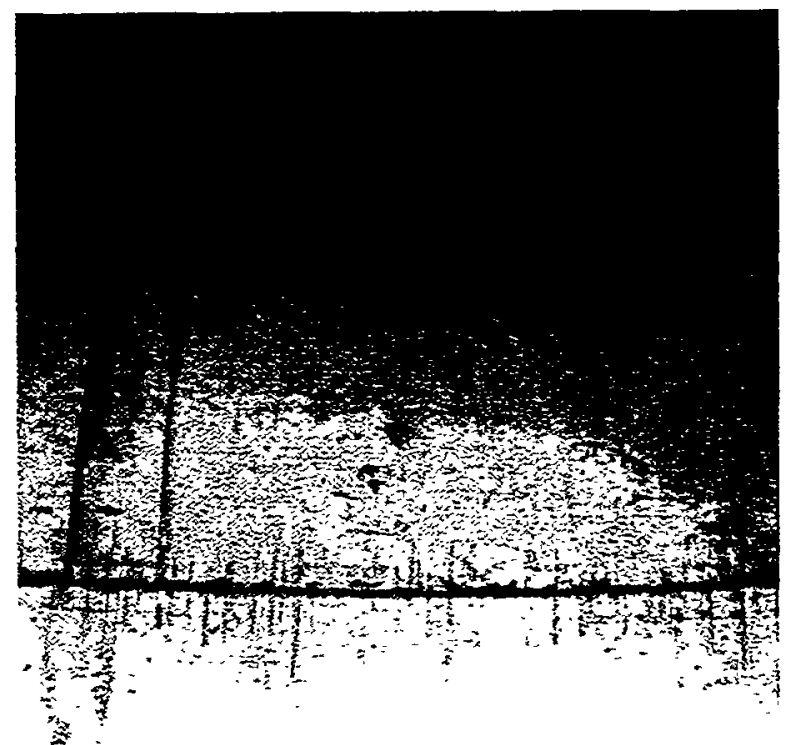

FICURE 9.6

Curious rusl-colored verlic al slreaks along internal circumlerential iveld scams in a 316 (UNS S31603) SS lank cxposed ior scveral weeks to the same condilions described in Figure 9.1.' 


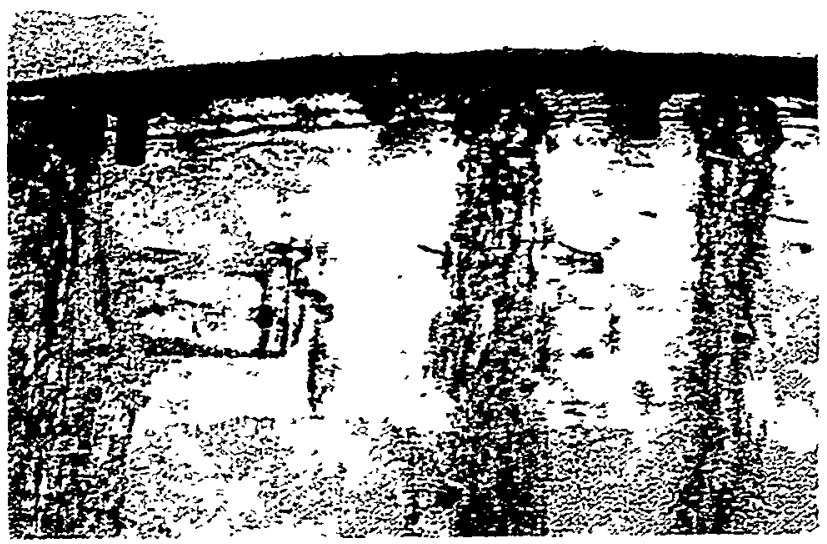

FIGURE 9.9

External streaks emanating from a 304 SS weld under internal iron bacteria (Gallionella) biomound deposits in a recirculating cooling water system using river water as makeup. ${ }^{2}$

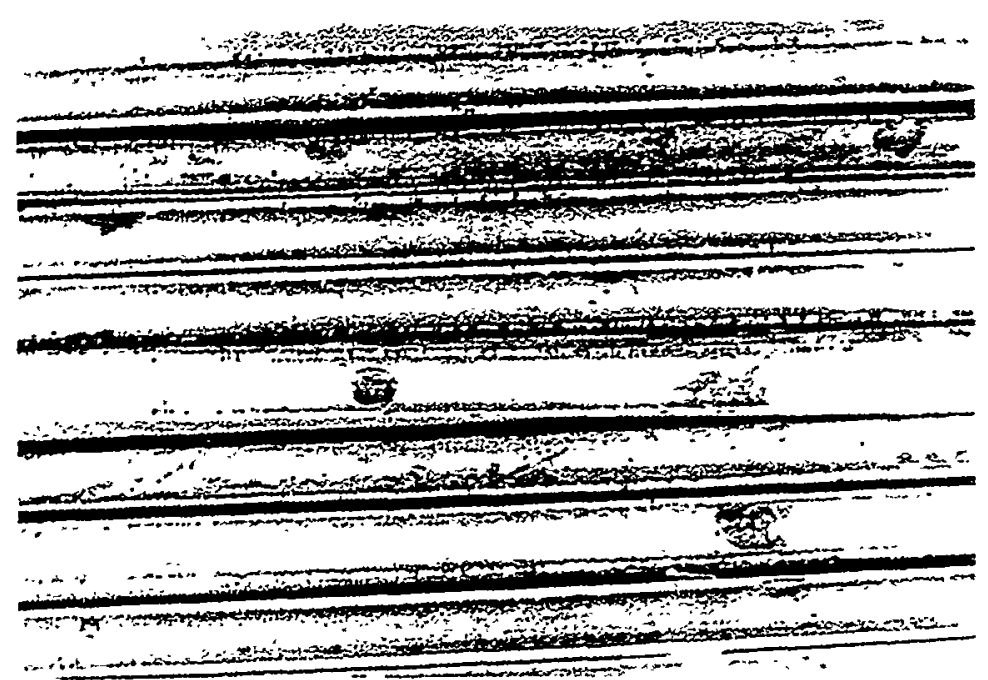

FIGURE 9.11

Internal surfaces of several 3/4 in. O.D. 304 SS tubes from a condenser exposed for one year to cooling tower water with raw bayou (fresh) water as makeup. Rust-colored stains that remained after high pressure water cleaning are believed to be sites of biomound deposits from unidentified iron/manganese-utilizing bacteria.'

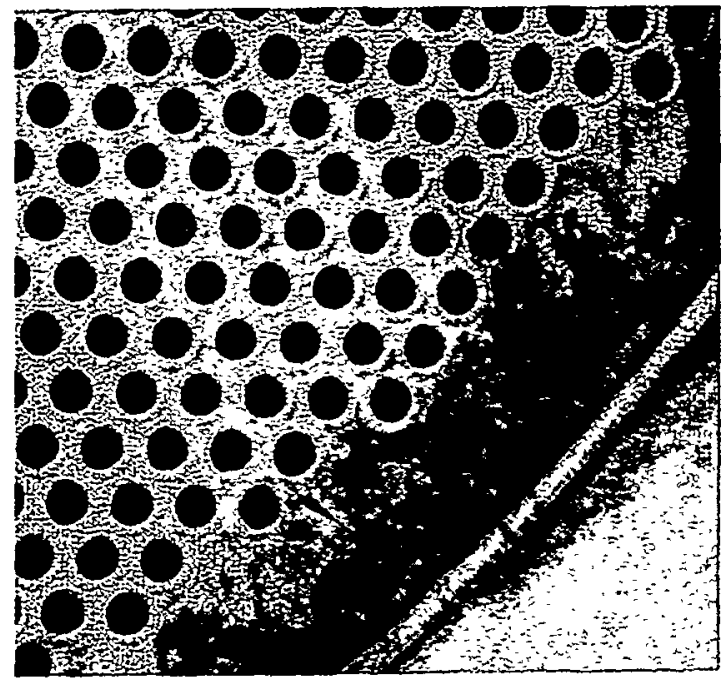

FIGURE 9.10

Surface of 308 (UNS S30800) SS weld-clad tube sheet in a condenser after removal of heavy biomound deposits (unidentified iron/ manganese-utilizing bacteria). Weld cladding was severely corroded after approximately 5 years' exposure to cooling tower water with raw river water as makeup.'

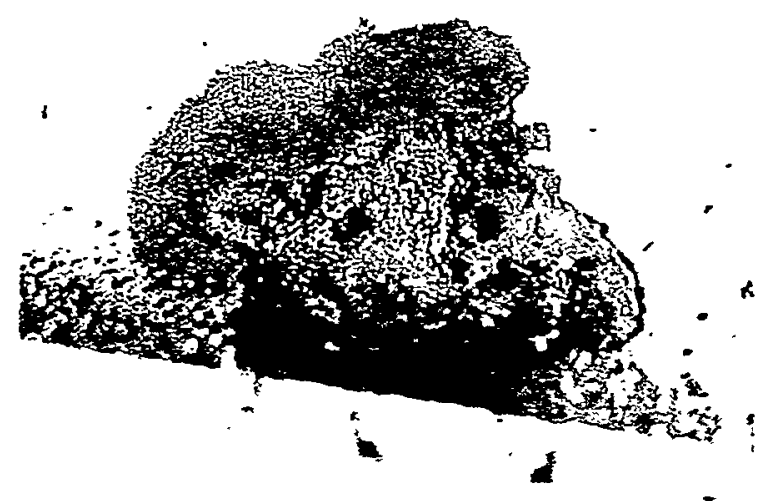

FIGURE 9.12

Coscup of one of the siles shown in Figure 9.11. Nole pils : sssoc ialcel with site. Approximately $3 X .{ }^{\prime}$ 


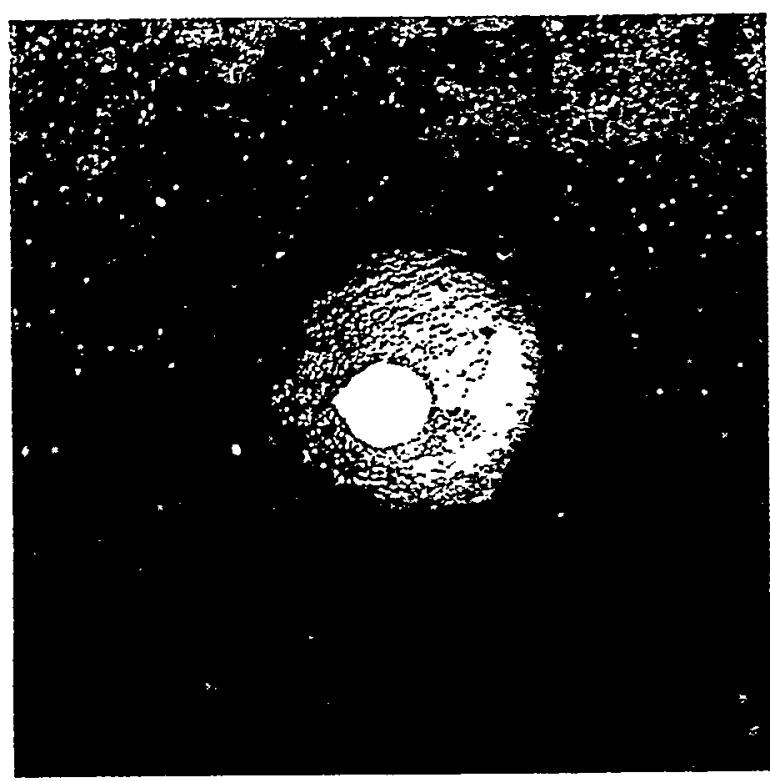

FIGURE 9.17

Pit and perforation in internal surface of plain carbon steel pipeline exposed to sweet crude oil for eleven months. Pit morphology is typical of corrosion by sulfate-reducing bacteria (SRB). Approximately $1.5 \times .^{4}$

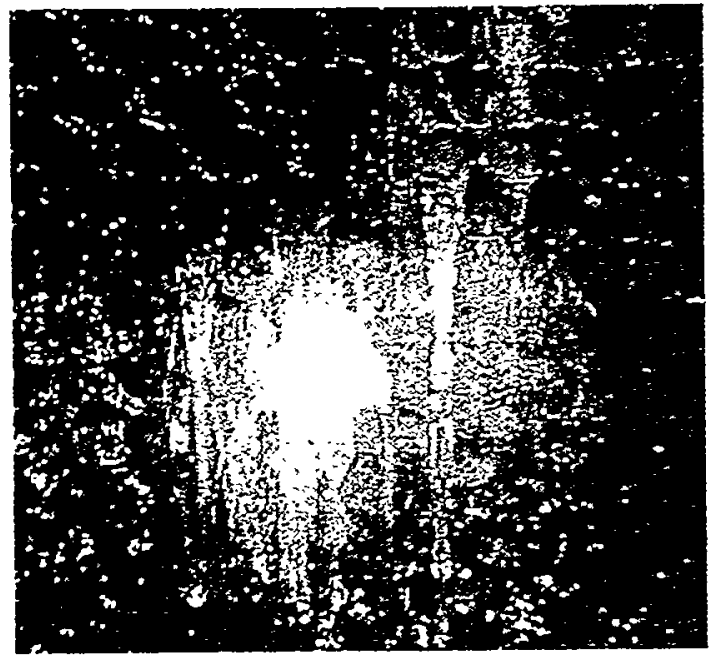

FIGURE 9.18

Microbiological slime being backwashed from a heat exchanger. Note biomass and black slime deposits containing sulfides adhering to plain carbon steel tube sheet. ${ }^{4}$

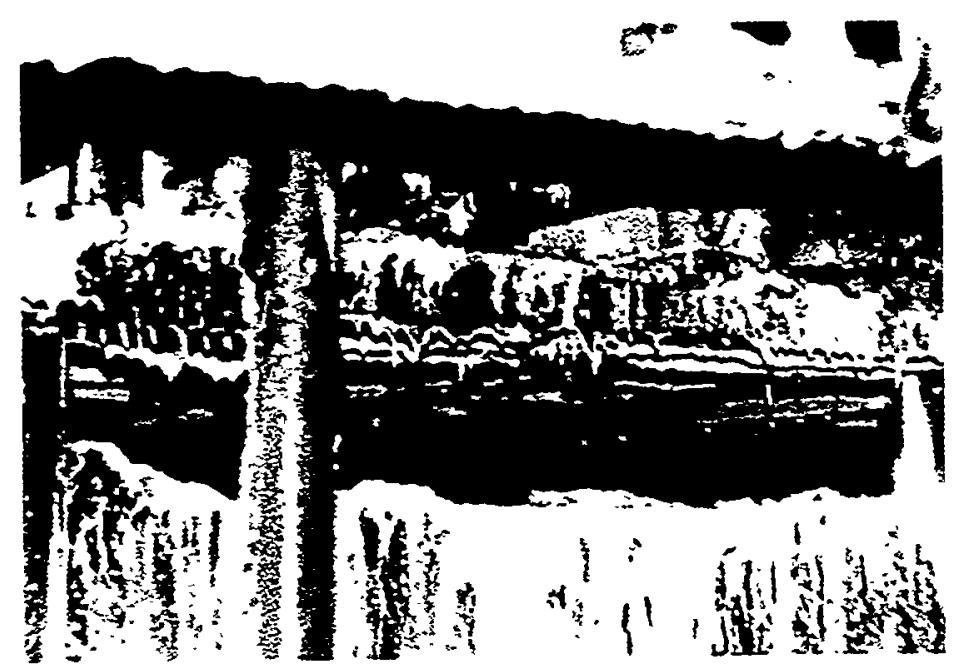

FIGURE 9.19

Microbiological slime caused by the uncontrolled growth of both fungi and bacteria in a cooling water system. ${ }^{4}$

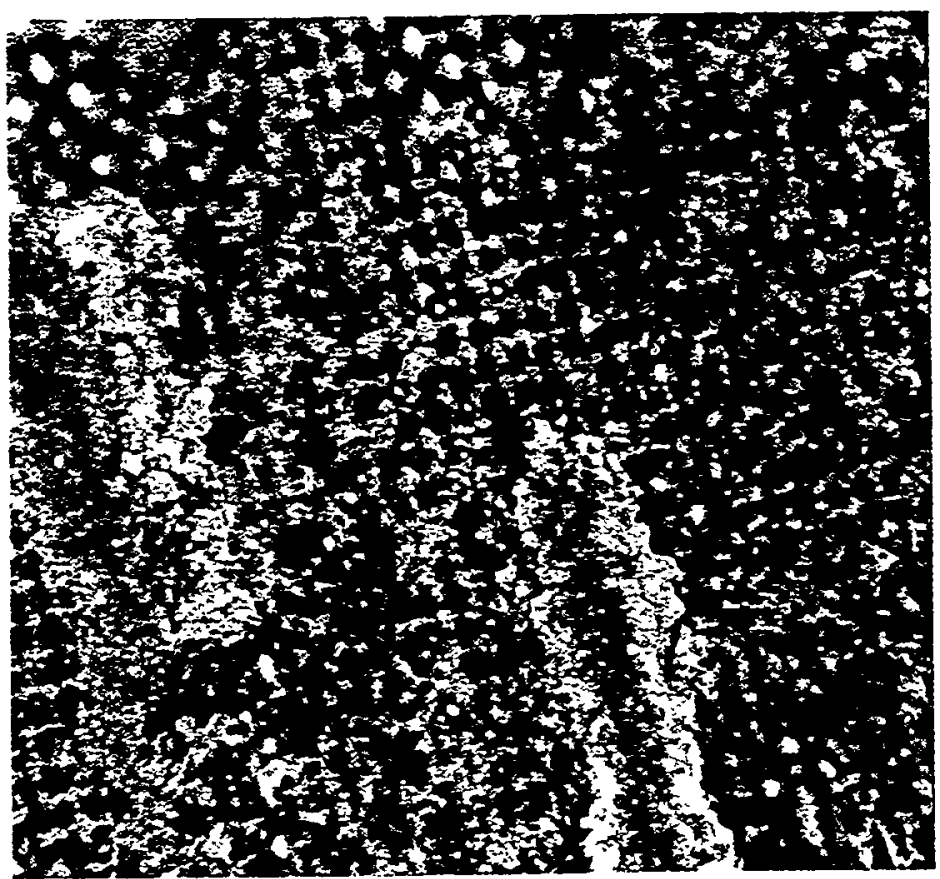

FIGURE 9.20

Cooling water intake screen parlially iouled wilh biomass and other debris. ${ }^{4}$ 